\title{
Long-Lasting Bank Relationships and Growth of Firms
}

\author{
Alessandro Gambini \\ Alberto Zazzaro
}

CESIFO WORKING PAPER NO. 3106

CATEGORY 11: INDUSTRIAL ORGANISATION

JUNE 2010

An electronic version of the paper may be downloaded

- from the SSRN website:

- from the RePEc website:

- from the CESifo website:

www.SSRN.com

www.RePEc.org

www.CESifo-group.org/wp 


\title{
Long-Lasting Bank Relationships and Growth of Firms
}

\begin{abstract}
A puzzling but consistent result in the empirical literature on banking is that firms with close bank ties do not grow faster than bank-independent firms. In this paper, we reconsider the link between relationship lending and firms' growth, distinguishing firms by size and "health". The idea is that the beneficial effects of relationship lending on information asymmetries can be compensated by other negative capture, risk and externality effects which make relational banks reluctant to support long-term growth projects of client firms, and that the strength of these compensating effects varies with firm size and health status. We explore the influence of long-lasting bank relationships on employment and asset growth of a large sample of Italian firms. The main finding is that relationship lending hampers the efforts of small firms to increase their size, while it mitigates the negative growth of troubled, medium-large enterprises.
\end{abstract}

JEL-Code: G21, G34.

Keywords: relationship lending, capture effects, firms' growth.

Alessandro Gambini

Università Politecnica delle Marche

Money and Finance Research Group

Department of Economics

Piazzale Martelli 8

Italy-60121 Ancona

a.gambini@univpm.it
Alberto Zazzaro

Università Politecnica delle Marche

Money and Finance Research Group

Department of Economics

Piazzale Martelli 8

Italy-60121 Ancona

a.zazzaro@univpm.it

We wish to thank Piero Alessandrini, Carlo Altavilla, Marco Lilla, Jack Lucchetti, Lars Norden, Andrea Presbitero, Franco Spinelli, Carmine Trecroci and Timo Wollmershäuser for comments and suggestions. Our thanks also go to seminar participants at the University of Brescia, University of Naples 'Parthenope', University of Milan and at the MoFiR conference on The changing geography of money, banking and finance in a post-crisis world (Ancona, Italy) and the Cesifo-Delphi conference on Financial markets, corporate governance and macroeconomic outcomes (Munich, Germany). Usual disclaimer applies. 


\section{Introduction}

A well-received argument in the banking literature is that close long-lasting lending relationships allow banks to acquire proprietary information on borrowers, softening asymmetric information problems and facilitating inter-temporal smoothing in loan contract terms (Boot 2000; Udell 2008). As a result, bank-dependent firms should benefit from easier access to finance, especially in the long term, and display higher rates of growth than independent firms. In contrast, however, empirical evidence consistently documents that firms closely tied to a main bank do not grow faster than other firms. Nakatani (1984), for example, considers the growth rate of sales revenue for 317 Japanese firms in the period 1974-1982 and finds that firms belonging to a keiretsu (a set of companies with interlocking relationships and shareholdings, typically centered around one main bank) do not perform better than non-member firms. Weinstein and Yafeh (1998) and Miarka (1999) extend the analysis to a large sample of small and large Japanese enterprises in the periods 1977-1986 and 1985-1998, respectively, once again clearly rejecting the hypothesis that main bank clients grow more rapidly than other firms. Agarwal and Elston (2001) analyze the annual growth rate of sales for a sample of 100 large enterprises in Germany in the period 1970-1986. Even after wiping out the influence of unobserved individual fixed effects, their regression results indicate that close bank-firm relationships are not significantly associated with faster growth rates of firms (see also Elston 2002) ${ }^{1}$. Finally, Shin and Kolari (2004) focus on whether fast-growing firms are more likely to borrow from main banks, and cannot find any association between these two variables for a large sample of non-financial listed companies in Japan.

This baffling evidence has been explained by referring to a number of conceivable factors, like the greater risk-aversion of main banks (Weinstein and Yafeh 1998; Chirinko and Elston 2006), firm concern for the secrecy of growth investment opportunity (Agarwal and Elston 2006) or the incentive for main banks to inefficiently rescue their customers (Chirinko and Elston 2006), which counterbalance the positive effects of greater and more reliable information.

However - and this is our research hypothesis - the missing link between relationship lending and firms' growth may be not missing at all. It could simply be the result of ignoring firm heterogeneities in the empirical analysis and in particular the existence of possible opposite links between the two phenomena for small versus large and for healthy versus troubled firms. For example, while main bank risk aversion, conflict of interests and survival bias can sensibly apply to large firms and justify a negative impact of close bank ties on their growth, they are much less compelling motivations if applied to small firms whose growth should only benefit from the information disclosure triggered by close

\footnotetext{
${ }^{1}$ In a similar vein, Houston and James (2001) study the investment behavior of bank-dependent firms and conclude that in the US "banks are unwilling to finance relatively large capital expenditures and thus bank-dependent firms must rely more on internally generated funds for these types of expenditures" (p. 349). See also Yafeh and Yosha (2003) who show that in Japan bank-dependent firms invest less in R\&D than independent firms.
} 
bank ties. By contrast, the reciprocal hold-up problems occurring over the course of a bank-firm relationship might cause small (large), healthy (unhealthy) bank-dependent firms to grow at a slower pace than other similar small (large), but bank-independent firms.

In this paper, we consider the correlation between the length of the credit relationship with the main bank and the firm's growth rate for a large panel of Italian manufacturing firms in the period 19982003. First, we split our sample into small and medium-large firms and analyze the average conditional effect of the length of credit relationships on firms' employment and asset growth. Second, we study the differentiated impact of long-lasting bank relationships on the growth rate of healthy and unhealthy firms by distinguishing between expanding and downsizing firms. In particular, by using three different econometric methods, we address three interrelated questions. First, by quantile regressions we assess the impact of the length of bank-firm relationship on the upper and lower tails of growth distribution. Second, by multinomial logistic regressions we study the likelihood of bank-dependent firms growing at a positive, negative or zero rate. Third, using the Heckman two-step procedure we distinguish the impact of close bank ties on the firms' decision to grow or downsize from the effect on the choice of how much they want to expand or shrink.

To briefly anticipate our results, we find that the conditional mean growth rate of small enterprises is negatively affected by the maintenance of long-lasting ties with a bank, while the growth performance of medium and large enterprises increases with the length of the relationship, although this latter effect is not statistically very significant. Furthermore, we find that the positive growth of small enterprises is negatively influenced by relationship lending, while, if in trouble, small enterprises do not have any special support from their long-lasting lenders. On the contrary, we find that when in trouble, large firms can take advantage of close ties with banks that limit their negative growth.

Besides distinguishing firms by size and health conditions, we improve upon the previous literature on firms' growth and relationship lending on several other grounds. First, we introduce relationship banking into a Gibrat equation. Other studies have estimated Gibrat's law augmented by capital structure and financial factors ${ }^{2}$, but no one has hitherto considered relationship banking variables. Second, while the previous literature on growth and relationship lending has followed a dummy approach by distinguishing the status of firms into bank-dependent and independent on the basis of the direct and indirect ownership held by the bank in each firm, we measure relationship banking by the length of the relationship with the main bank. This makes our results easily comparable with studies on financial and real effects of close bank ties which typically use the length of the lending relationship as a proxy, and allows corporate governance to be separated more neatly from lending issues. Third,

${ }^{2}$ See Lang et al. (1996), Heshimati (2001), Becchetti and Trovato (2002), Carpenter and Petersen (2002), Honjo and Harada (2006), Oliveira and Fortunato (2006). 
following recent contributions on bank-firm relationships ${ }^{3}$, we address the possibility of reverse causality between firms' growth and bank relationships and omitted variables by using a two-stage instrumental variable estimator. Finally, we consider both the growth of firms' total assets and current employment.

The rest of the paper proceeds as follows. In Section 2, we discuss the theoretical background and related literature. In Section 3 we describe the dataset, empirical model, variables and estimation methodology. In Sections 4, 5 and 6 we present our econometric results, followed by our conclusions in Section 7.

\section{Why should main banks influence the growth of borrowing firms?}

Where credit markets are plagued by asymmetric information problems, by establishing close, longlasting ties with firms, main banks gather exclusive information on the latter, thereby reducing the cost of assessing risk and profitability of their long-term investment projects and ensuring they have the possibility to extract rents in the future. This facilitates access to finance for bank-dependent firms, especially if small-sized ${ }^{4}$, and should allow them to take every opportunity to grow fast. However, the benefits of this information effect on credit availability for growth can be offset and even overwhelmed by other effects in the opposite direction.

For example, risk and externality effects may be at work. As relational banks hold most of their borrowing firms' debt, they may prefer to avoid financing risky long-term investment projects, even if profitable, or decide to protect the firm management against profitable but risky hostile takeovers (Weinstein and Yafeh 1998; Chirinko and Elston 2006). In addition, in order to reduce negative externalities on other borrowers or to open up new business opportunities to them, relational banks might find it profitable to reveal private information about the firm's growth projects for which they are the main lender, thus dissipating the firm's crucial competitive advantages (Agarwal and Elston 2001). The importance of both these effects can be reasonably thought to increase with the size of borrowing, going so far as to overwhelm the information effect for large firms only. Applying this logic, the growth rate of small enterprises should be positively correlated with the exclusiveness (the length) of the lending relationship with main banks, while the growth rate of large enterprises should be negatively influenced by such ties.

\footnotetext{
${ }^{3}$ See Degryse and Ongena (2001), Fok et al. (2004), Herrera and Minetti (2007), Montoriol Garriga (2006), Alessandrini et al. (2009a, 2009b).

${ }^{4}$ Evidence that longer relationships with a lender increase credit availability for small firms is provided by Angelini et al. (1998) and Harhoff and Körting (1998) for European countries, and by Petersen and Rajan (1994), Berger and Udell (1995), Cole (1998), Chakraborty and $\mathrm{Hu}(2006)$ and Bharat et al. $(2007,2009)$ for the United States.
} 
In contrast, the traditional capture effects may hurt the growth process of small firms, while benefiting that of large firms. As is well understood in the literature, loan contracts undergo a "fundamental transformation" during their lives, from a competitive transaction towards a bilateral monopoly between parties. At the outset, both the lender and borrower have a large number of potential counterparts with whom they can do business. As the lending relationship goes on, however, a two-sided dependency arises, creating some monopoly power in favor of both parties. During the lending relationship, the bank invests in human, organizational and physical relation-specific assets and gathers soft, proprietary information on the firm's creditworthiness. This boosts the value of the relationship, but can lock the bank and the firm into the relationship, the former captured by the latter and vice versa. On the one hand, the informational advantage gained by the lender makes it costly for the firm to escape from the relationship (Sharpe 1990; Rajan 1992). On the other, the greater the resources invested in the relationship the harder it is for the bank to terminate the loan contract, even when the firm is suffering and its economic prospects have deteriorated (Dewatripont and Maskin 1995; Longhofer and Santos 2000).

Reciprocal hold-up problems may influence firms' growth performance in a number of ways. First, informationally-captured firms can rationally anticipate that much of the rent from their investments will be extracted by the relational bank and therefore reduce their growth effort (Rajan 1992). Second, to the extent that informational rents and market power of banks decrease with the borrower's size (Petersen and Rajan 1995), when funding the positive growth of existing clients, relational banks have to balance the benefit of lending to a larger client in the future with the cost of a decrease in market power over the same client and in the share of profits extractable in the credit relationship. If the chances of a borrower escaping from a bank relationship are slim and the costs of switching to another lender are high (i.e. if the bank captures the firm), relational banks may find it relatively unprofitable to finance the rapid growth of enterprises, while they have an interest in driving small firms towards growth-neutral investments. Third, the bank's capture by the firm sets in motion soft-budget-constraint phenomena (Dewatripont and Maskin 1995), that may influence both the expansion and downsizing decisions of firms. Having invested a great amount of relation-specific resources in the customer relationship, the bank is strongly interested in rescuing the firm when in trouble and limiting its negative growth (and possible failure). On the contrary, captured banks can only feebly withstand the financing demands of firms that may overoptimistically invest in their growth.

Insofar as information problems tend to be severer and switching from one bank to another more difficult for small than for large firms, it may be reasonably conjectured that the former are more likely

5 This expression is due to Williamson $(1976 ; 1985)$. 
to be captured by relational banks than the latter ${ }^{6}$. By contrast, given that the larger the borrowing client the more specific resources banks devote to relationships, large firms may capture banks ${ }^{7}$. Therefore, where capture effects dominate information effects, we expect to observe small, healthy firms with long-lasting bank ties to grow significantly less than small, healthy bank-independent firms, while large bank-dependent firms to grow faster. On the other hand, large unhealthy firms with longlasting bank ties are more likely to be supported by their banks than similar bank-independent firms, and the former should downsize at a significantly lower rate than the latter. By contrast, the likelihood of small firms being supported by banks when in trouble should not be significantly affected by the exclusiveness of the relationship.

\section{Dataset, estimated model and summary statistics}

\subsection{Data}

The whole set of firm-specific information as well as information on the duration of the credit relationship with the main bank are drawn from the Indagine sulle Imprese Manifatturiere, a survey carried out on manufacturing firms by the Italian banking group Unicredit (formerly, by Mediocredito Centrale and Capitalia) every three years ${ }^{8}$. We considered the waves run in 2001 (covering the 19982000 period) and 2004 (covering the 2001-2003 period). The survey targets manufacturing firms with more than 10 employees: the universe of firms with more than 500 employees and a stratified sample of firms with 11-500 employees ${ }^{9}$. The sample is fairly representative of the Italian economic structure: 66 percent of firms have less than 50 employees, while 91 percent are below the threshold of 250

\footnotetext{
${ }^{6}$ Consistent with the hypothesis that relational banks capture small firms, many studies concerning countries other than the USA have found that interest rates and collateral on small business loans increase with the length of the lending relationship and that the usage rates of credit lines decrease for older customers (Angelini et al. 1998; Degryse and Van Cayseele 2000; Hernandez and Martinez 2006; Ono and Uesugi 2005; Barone, Felici and Pagnini 2006; Ogawa et al. 2007; Grunert and Norden 2009; Jiménez et al. 2009; Ioannidou and Ongena 2010). In addition, the profitability of small firms tends to be lower when they maintain exclusive relationships with few banks (Montoriol Garriga 2006). By contrast, Degryse and Ongena (2001) and Fok et al. (2004) found that exclusive relationships with banks improve performance of large publicly listed firms.

${ }^{7}$ Sakai et al. (2005), analyzing a large panel of small Japanese firms, found that firms that defaulted during the sample period pay higher interest rates than survivors regardless of their age, thus indicating that banks do not have incentives to support and subsidize small troubled borrowers. Similarly, Brunner and Krahnen (2008) showed that in Germany the probability of a pool of banks forming to revitalize distressed small-medium enterprises is greater when the firm debt is evenly distributed among a large number of banks. By contrast, evidence on the capture of relationship lenders by large firms has emerged for the Japanese economy especially during the crisis of the 1990s. Hoshi et al. (1990) found that firms under financial distress experience a relatively modest contraction in their investments and sales if they belong to industrial groups including their main bank (keiretsu). Kawai et al. (1996) reported that interest-rate premia paid by firms at the time of financial distress are significantly lower if they rely on the same largest bank lenders for at least ten years. Peek and Rosengren (2005) showed that large troubled firms with strong bank ties are more likely to obtain additional loans than other firms.

8 This survey has been widely used in banking literature. Amongst others see Herrera and Minetti (2007); Benfratello et al. (2008); Alessandrini et al. (2009a; 2010); Presbitero and Zazzaro (2009).

9 The sample is stratified by size (distinguishing five classes according to the number of employees), geographical macroareas (Centre-North and South) and industrial macro-sectors (according to the Pavitt classification).
} 
employees; about 70 percent are headquartered in northern Italy; more than 50 percent of the firms operate in traditional sectors, as defined by the Pavitt classification, while only 5 percent are high-tech.

Each wave contains over 4,000 firms with almost half of the firms being replaced by new firms in each survey (rotating panel). Replacement may be due to several reasons such as firms ceasing their activity, not belonging any longer to the manufacturing sector, reducing the number of employees below 11 or simply ending their participation in the survey. Unfortunately, it is not possible to distinguish between these cases and hence control for the survival selection bias.

After checking for inconsistencies, outliers and missing values, between 5,264 and 5,440 observations were available for our regression analysis. The survey data are complemented with information on the Italian banking market at the provincial level based on Bank of Italy statistics and drawn from Alessandrini et al. (2009a) ${ }^{10}$.

\subsection{Growth model and estimation strategy}

We estimate a growth equation à la Gibrat, augmented by a learning-by-doing effect (Jovanovic 1982), some firm-specific controls and the length of the relationship with the main bank ${ }^{11}$ :

$$
\text { Growth }=\alpha+\beta_{1} \text { Size }_{i t}+\beta_{2} A g e_{i t}+\beta_{3} \text { Main-bank relationsiplength }+\sum_{j=1}^{n} \gamma_{j} X_{j i t}+\varepsilon_{i t}
$$

Growth is the average annual growth rate of firm size over the survey wave period:

$$
\text { Growth }=\frac{\left(\ln \text { Size }_{i t+2}-\ln \text { Size }_{i t}\right)}{2}
$$

where $t$ is the first year of each survey's wave. The rate of growth is computed, alternatively, in terms of current employment and total assets (see Table 1). As pointed out by Sutton (1997), when the span of time considered in the analysis is not very long, there can be systematic differences between employment- and asset-growth rates. To illustrate, the decision to either increase or decrease the number of employees imposes investments and sunk costs, especially in the presence of high employment protection and firing costs as in the Italian job market ${ }^{12}$. Therefore, it well approximates an informed, long-term corporate project, which is irreversible in the very short run and may have a permanent impact on the firm's main bank, calling for new financial resources and risk involvement (in the case of positive growth) or leading to loan cuts and financial losses (when the growth is negative).

\footnotetext{
${ }^{10}$ A detailed description of variables used in the analysis and their sources is reported in Table 1.

11 Typically, empirical models for Gibrat's law also include Size and Age squares and the interaction term between Size and Age. In our sample, however, these terms are generally insignificant and increase standard errors for Size and Age, whereas their inclusion leaves sign and magnitude of other covariates (in particular, of Main-bank relationship length) virtually unchanged (results are available on request from the authors).

12 Statistics on the OECD Employment Protection Law Index (OECD 2004) concerning the difficulty of dismissal indicate that Italy is one of the countries with the strictest labour protection laws among OECD members, unlike English-speaking countries which have the least restrictive legislation.
} 
By contrast, the growth of total assets experienced by a firm at the end of each year, while surely depending on deliberate corporate activities, it also reflects the firm's market success and may be affected by transitory economic conditions. When the asset-growth rate is averaged over a short time interval (in our case only a three-year period) the transitory element can be predominant and what matters is the flexibility of financial resources guaranteed by banks, rather than banks' willingness to support a stable, long-term investment project.

\section{[Insert Table 1]}

Equation (1) is estimated for the whole sample and for the subsamples of small and medium-large firms. We follow the size classification adopted by the European Commission during our period of analysis according to which those firms with fewer than 50 employees and total assets less than 5 million euro are small, and the others medium-large ${ }^{13}$. During the three-year period 59 firms changed their size status, the great majority (46) growing from small to medium-large enterprises ${ }^{14}$. On average, small firms increased their employment at a yearly rate of 1.2 percent, less than medium and large firms (1.4), while in terms of assets the growth was 4.4 percent for small firms and 3.1 for medium-large firms (Table 2).

For the sake of comparison with the previous literature, first we look at the effects of long-lasting bank relationships on the conditional-on-covariates mean of firms' growth rate by running OLS and instrumental variable estimates for the whole Unicredit sample and for the sub-samples of small and medium-large enterprises. Then we introduce a second source of firm heterogeneity by distinguishing between healthy and unhealthy firms. In particular, we consider firms with positive growth during the three-year study period as healthy, and firms that downsize as unhealthy. On this point, we diverge from the literature on firms' restructuring which typically classify firms into distressed and nondistressed on the basis of accounting indicators of profitability or debt-servicing capacity. However, as is known, such measures suffer from window dressing or misreporting problems. Moreover, any threshold criterion for profitability or debt-servicing capacity is very subjective. Diversely, the decision to grow or downsize (especially when measured in terms of employees) is less influenced by windowdressing motives or misreporting, even though highly correlated with the operating performance of the firm (Kang and Shivdasani 1997) ${ }^{15}$.

\footnotetext{
13 This definition of small firms has been replaced by Recommendation 2003/361/EC (May 2003) by which the Commission raised the total asset threshold to 10 million euro.

14 All the exercises showed in the following sections have also been run omitting the firms changing in size status during the sample period, and results are robust in sign, magnitude and significance of coefficient estimates.

15 In our samples the correlation coefficients between return on assets and the growth of employment and total assets range between 0.08 and 0.13 and are always statistically significant at the 99 percent level. In addition, the average rates of employment and total assets growth for the sub-sample of firms with a return on assets above the median (or the mean) are statistically higher with a 99 percent level of significance (similar results hold when we classify the firms' health status on the basis of the ratio between the pre-tax operating income and interest expenses).
} 
In order to study the effect of long-lasting relationships on growth and downsizing decisions, we follow three different empirical strategies. First, we model the entire growth rate distribution by running quantile regressions. In this way, we can assess the existence of asymmetric effects of the credit relationship duration in the lower and upper tails of growth distribution. Second, we focus on firms' employment-growth rate to assess whether enduring bank ties have different effects on the likelihood of firms increasing or reducing employment and on the intensity of positive and negative growth performance. In order to address these questions we run multinomial logistic regressions for a categorical variable distinguishing firms that increase, decrease or leave unaltered the number of employees during the survey period, and estimate two selection models by following the two-stage Heckman procedure for positive and negative growth rates, respectively.

\subsection{Explanatory variables}

\subsubsection{The length of the bank relationship}

The closeness of a bank-firm relationship is not an easy phenomenon to measure (Boot 2000). A proxy for relational lending widely used in the literature is the span of time since when the firm and its main bank were tied, the basic idea being that the longer the relationship, the greater the availability of proprietary soft information and the specific resources invested by the parties in the relationship, and the more difficult it is for the bank and the firm to escape from the relationship (Petersen and Rajan 1994, Berger and Udell 1995, Degryse and Van Cayseele 2000, Ongena and Smith 2001, Elsas 2005).

In the Unicredit survey, firms are asked for how many years they have borrowed from the current main bank, that is from the bank that holds the largest share of the firm's debts. The question explicitly refers to the last of the three years covered by the survey, and therefore the responses cannot be directly used to explain firm growth during the three-year period. In order to antedate these responses to the first year of the survey period we consider as relational only those ties between a firm and its main bank lasting more than three years. In particular, assuming that firms have not changed their main bank during the three-year survey period, the duration of the credit relationship is computed as follows:

$$
\text { Duration } \begin{cases}0 & \text { if Credit legth } \leq 3 \\ T=(\text { Credit legth }-3) & \text { if Credit legth }>3\end{cases}
$$

where Credit length is the firm's response to the survey question ${ }^{16}$. Thus defined, the average length of the credit relationship with the main bank is about 14 years, and it is statistically greater for mediumlarge (15.3 years) than for small enterprises (13.3) at any conventional level of significance. Moreover, small firms with positive growth have significantly shorter credit relationships (11.7 and 12.7 years depending on whether we consider the employment or asset growth rate) than those downsizing (14.7

\footnotetext{
${ }^{16}$ The number of firms for which Credit length is equal to 1 and 2 years are 24 and 105 respectively.
} 
and 14.3). Assuming that the marginal effects of main-bank relationships on firms' growth are decreasing, in the regression analysis we consider the logarithmic transformation of Duration. To be precise, in equation (1) Main-bank relationship length is given by $\ln (1+$ Duration).

[Insert Table 2]

It is worth noting that in each survey firms are also asked how many banks they were operating with at the end of the survey period and what was the share of the debt provided by the main bank. However, to antedate these responses to the beginning of the growth period it is not sufficient to assume that the identity of the main bank is the same, as for Duration, but one should also assume that the importance of the main bank and the number of non-main banks with which the firms do business are unchanged during the survey period. As these assumptions are much less reliable than that on the main bank identity, in our analysis we focus only on the length of the credit relationship.

\subsubsection{Control variables}

As in classical Gibrat regression models, the two main control variables are the initial size of the firm and its age. In accordance with the growth variables, Size is measured alternatively in terms of the firm's employees or assets value, in logarithm, at the beginning of the growth period. Age is computed as the logarithm of the number of years from the firm's inception to the time of the survey. Gibrat's law predicts that the firm's growth is not significantly affected by its initial size. By contrast, a negative significant impact of Size and Age on Growth would indicate that Gibrat's law is violated, while providing support to learning-by-doing models, predicting that well-managed firms grow rapidly and survive, while inefficient firms choose to contract or exit the market (Jovanovic 1982). As reported in Table 2, the average firm in the sample has 105 employees and assets of 21.1 million euro; small firms are usually younger (24 years old) than medium-large firms (30).

Then we control for a set of financial and non-financial firm characteristics that are expected to influence growth rates. First, we consider the availability of internal and external financial resources. The former is proxied by the ratio of cash flow to total assets (Cash flow) and by a dummy variable that takes the value of 1 if the firm belongs to a formal corporate group and 0 otherwise (Group). A positive significant correlation between cash flow and growth is usually interpreted as firms being financially constrained on the credit markets (Carpenter and Petersen 2002). Group, instead, captures the effect that access to the capital market internal to the group has on the firm's growth rate. If the internal capital market allocates resources to sound firms efficiently, Group is expected to have a positive sign. On the contrary, if the internal capital market is used for incentive purposes (Rajan et al. 2000) or to drain resources out of affiliated firms to the benefit of controlling shareholders at the 
parent holding (Johnson et al. 2000), the coefficient on Group may also assume negative and significant values.

Access to external finance is proxied by the ratio of firms' debts to total assets (Leverage). This index is ambiguously associated with the firm's growth. From a theoretical point of view, the literature on the optimal capital structure gives good reasons to predict that, in the presence of asymmetric information and transaction costs, Leverage could be correlated both positively and negatively with a firm's profitability and growth prospects (Jensen and Meckling 1976; Ross 1977; Stulz 1990). Moreover, the leverage ratio contains information not only on the firm's optimal capital structure, but also on its riskiness, actually reflecting both the factual and potential access to external finance. Hence, not surprisingly, empirical studies have found positive, negative and non-significant correlations between Leverage and Growth (Opler and Titman 1994; Lang et al. 1996; Heshmati 2001; Becchetti and Trovato 2002; Honjo and Harada 2006).

Other controls concern the firm's propensity to export and innovate. The former (Export) is measured by a dummy variable that takes the value of 1 if the firm exports part of its production in the last year of the survey and 0 otherwise. The latter $(R \& D)$ is measured by a dummy variable that takes the value of 1 if the firm made R\&D investments during the three-year survey period and 0 otherwise. Both Export and $R \& D$ are expected to be positively correlated with the firm's growth.

For robustness, in some specifications we also control for the mode of growth, the concentration of the local credit market, the "localism" of the main bank, credit rationing, multiple lending and the judicial efficiency in recovering bad loans. In particular, we build: (i) a dummy variable, $M \& A$, taking the value of 1 if the firm grows by merging or acquiring other firms during the survey period and 0 if it grows only internally; (ii) the Herfindahl-Hirschman index calculated in terms of the share of branches at the provincial level; (iii) a dummy variable, Local bank, taking the value of 1 if the firm's main bank is headquartered in the same province as the firm's official headquarters; (iv) a dummy variable, Credit rationing, taking the value of 1 if the firm reports it has sought more credit at the interest rate agreed with the bank and 0 otherwise; (v) the number of bank relationships at the end of the three-year growth period (Number of banks); (vi) the average length of bankruptcy trials in the province where the firm is headquartered (Fail).

Finally, we code dummies to control for a set of fixed effects accounting for the industrial sector (Industry), the firm's geographical location (Area) and the economic cycle (Year).

\section{Long-lasting bank ties and the firm's average growth rate}

\subsection{OLS estimations}


Table 3 reports OLS results for the regression model (1) relative to the overall sample (Panel A) and the two subsamples of small and medium-large enterprises (Panels B and C), using both employment- and asset-growth rates as dependent variables.

\subsubsection{Long-lasting bank ties}

With regard to our key explanatory variable, if we look at the whole sample, the impact of the length of credit relationship with the main bank on the firm's growth rate is not significantly different from zero, regardless of the measure of growth we adopt. At first sight, this finding is in line with evidence for Germany and Japan (see the Introduction), suggesting that firms are neither sustained nor impeded by their main banks in their growth objectives. However, things change when we split the sample into small and medium-large enterprises.

When we consider small firms, the length of the main-bank relationship proves negatively correlated to employment- and asset-growth at 5 percent level of significance. The economic impact is similar in magnitude and is robust to further controls for the mode of growth, market concentration and main bank "localism". To illustrate, in specifications (5) and (6) an increase in Main-bank relationship length from the $25^{\text {th }}$ to the $75^{\text {th }}$ percentile of its (sub-sample) distribution causes the average firm to decrease its employment (asset) growth from 1.37 (4.59) to 0.95 (3.84) percent. In the case of medium-large enterprises, the average growth rate of total assets as well as the increase (or decrease) in the number of employees is not affected by Main-bank relationship length whose estimated coefficient (positive in sign) is statistically not different from zero. These results indicate that the link between relationship lending and firms' growth is not unequivocal. For small firms, the beneficial impact of close bank ties on access to credit is overwhelmed by the adverse influence that capture, risk and externality effects have on the main bank's willingness to support their long-term growth projects. By contrast, for large firms, risk and externality effects only offset information effects, as relational banks cannot thwart the growth objectives of large borrowers, for whom the threat of switching to another lender is a credible weapon to obtain adequate financial support from the main bank .

[Insert Table 3]

\subsubsection{Gibrat's law and other control variables}

The first result that clearly emerges is violation of Gibrat's law: in other words, the growth rate of firms is not independent of their initial size. Specifically, firm size at the beginning of the period does negatively and significantly influence, at the 1 percent level, employment- and asset-growth rate. 
Interestingly, although our data do not allow us to consider the well-known survival selection bias ${ }^{17}$, Gibrat's law does not hold even in the small-firm subsample, where the effect of firm size on the likelihood of surviving should be definitely lower than for large firms.

Secondly, in accordance with Jovanovic's theory of learning-by-doing, we find a negative relationship between growth and Age especially for the asset-growth rate of small firms. The joint negative sign of Size and Age variables is in line with much of the empirical literature testing Gibrat's law (Evans 1987; Hall 1987; Dunne et al. 1989; Dunne and Hughes 1994).

As for the capital structure variables, the positive and highly significant sign of Cash flow indicates the existence of financial constraints to firm growth (Carpenter and Petersen 2002). The coefficient of Cash flow is always significant at the 1 percent level and the marginal impact is unexpectedly greater in the subsample of medium-large than small enterprises. The leverage ratio, too, has a positive effect on firms' growth rate, but the magnitude of coefficients is lower than in the case of internal cash flow, suggesting the existence of asymmetric information in capital markets and of a pecking order of corporate financial sources (Ross 1977, Myers and Majluf 1984).

The importance of access to internally produced financial resources is confirmed by the positive correlation between Group and growth rate. The favourable effect of group membership is limited to the growth rate of employees, and it is more robust in the case of small enterprises.

As expected, both firm openness to international trade (Export) and investment in research and development $(R \& D)$ are significantly and positively associated to growth, especially when measured in terms of assets and in the case of small firms.

Finally, in specifications 3-4, 7-8 and 11-12 we add six more control variables for mergers and acquisitions, credit market concentration, main bank's location, credit rationing, multiple lending and judicial efficiency. As expected, firms involved in M\&A deals grow more, on average, than firms deciding to increase their employment and asset size on the inside only ${ }^{18}$. By contrast, operating in a more concentrated credit market and borrowing from a main bank headquartered locally does not have any significant impact on firms' growth. Credit rationing proves significantly and negatively related to the employment growth rate of medium-large firms, while it has no significant effect on the growth of small enterprises, suggesting that relationship lending acts through channels other than credit-quantity constraints. Number of banks is always significantly associated with the percentage growth rate, suggesting a positive impact of multiple lending on firms' growth. However, it must be acknowledged that the sign and significance of its coefficient may be flawed by a certain degree of endogeneity due to

\footnotetext{
17 According to the survival selection bias, the negative impact of initial firm size on their growth rate could be due to the fact that large, inefficient firms are more likely to survive than small, inefficient firms, which are therefore not observed and are excluded from the sample.

${ }^{18}$ It is worth noting that violation of Gibrat's law does not stem from the presence of M\&A (Ijiri and Simon 1977).
} 
the fact that information is collected at the end of the three-year period. Finally, the employment growth of small firms seems to suffer from a lower efficiency of judicial courts in bankruptcy trials (Guiso et al. 2004b; Jappelli et al. 2005).

\subsection{Instrumental variable estimation}

Reasonably, there are concerns that the length of the main-bank relationship can be correlated with the error term in the regression, producing biases and inconsistency in the ordinary least squares estimations. First, there can be problems of reverse causation with firms' growth prospects influencing the duration of ties with the main bank. For example, a firm that is planning future growth could decide to change its main bank in order to escape potential hold-up problems or, on the contrary, it can start to build a stable relationship in order to pass soft information to the bank. In turn, anticipating a firm's troubles (successes), the bank can interrupt (intensify) the lending relationship. Second, the length of the credit relationship with the main bank could mismeasure the exclusiveness and extension of the bank-firm relationship (which is the true explanatory variable for firms' growth) causing Main-bank firm relationship to be negatively correlated with the disturbance $\varepsilon_{i t}$ in equation (1). Third, it is reasonable to believe that the number of years that a firm has operated with the same main bank and the decision to increase its size may be affected by some common unobserved factors like the attitude to risk or the self-confidence of the firm owner/manager.

In order to address the problem of estimation bias in OLS we run instrumental variable regressions following a two-stage procedure. In the first stage we regress Main-bank relationship length on the variables in equation (1) plus a set of excluded instruments uncorrelated with Growth. In the second stage we estimate equation (1) with the fitted values for Main-bank relationship length from the firststage regression coefficients.

Following a consolidated literature (Guiso et al. 2004a; Herrera and Minetti 2007; Alessandrini et al. 2009a, 2009b) we use two groups of instrumental variables. One group captures the dynamics of bank branches in local markets during the period preceding our analysis: (i) the annual average number of branches opened by entrant banks in the province where the firm is headquartered during the period 1991-1998 (New branch entrants) ${ }^{19}$; (ii) the average number of new branches opened by incumbents net of closed branches in the firms' province in the same period (New branch incumbents). The other group of instruments measures the structure of local banking markets in 1936, when the Italian

\footnotetext{
${ }^{19}$ New branch entrants and New branch incumbents consider the absolute number of new branches opened in a province. For robustness we also considered instruments where new branches are normalized, alternatively, to the population or total branches in the province (Herrera and Minetti 2007; Alessandrini et al. 2009a, 2009b). Estimated coefficients are substantially unaltered, while the $F$-statistics on excluded instruments indicate a worsening of their significance.
} 
government passed a strict entry regulation that tightly constrained the opening of new branches in the provincial market until the late 1980s: (iii) bank branches per 10,000 inhabitants in the province (Branches); (iv-v) the share of branches owned, respectively, by saving and cooperative banks in the province (Saving banks and Cooperative Banks).

As noted by Herrera and Minetti (2007), there are no clear priors on the correlation sign between these instruments and the length of the credit relationship with the main bank. First, the opening of bank branches in provinces where saving and cooperative banks were few in number in 1936 proceeded at a slower pace until the late 1980s and then accelerated (Guiso et al. 2004a). Second, as the recent literature suggests ${ }^{20}$, increased competition in the local credit market has an ambiguous effect on the exclusiveness of bank-firm ties.

\section{[nsert Table 4]}

Results of IV estimations and diagnostics on significance, validity and the relevance of excluded instruments and exogeneity of Main-bank relationship length are reported in Tables 4 and 5. Looking at the Sargan test, the validity of instruments is clearly verified: the null hypothesis of valid overidentifying restrictions is never rejected at a high confidence level, indicating that none of the instruments are correlated with the error term in the structural equation and that they are correctly excluded from its estimation. For whole-sample specifications (columns 1-4), F-statistics on the excluded instruments in the first-stage regression allow us to reject the null that the instruments are jointly insignificant at 5 percent significance level. In the other specifications, the combination of instruments that are jointly significant differs by sub-subsample. For example, in the case of small firms (specifications 5-8) when we limit instruments to Branches, Saving banks and New branch entrants the $F$-test indicates rejection of the null at 5 percent level. However, for the sake of comparison, and given that point estimates of coefficients are pretty similar in magnitude and significance, we opted to maintain the same set of instruments through all the specifications.

Significance apart, the value of the first-stage $F$-statistics is quite far from the critical values of 10.83 and 4.84 tabulated by Stock and Yogo (2005) for the strong instrument tests based, respectively, on the two stage least square (TSLS) coefficients relative bias and the limited-information maximum likelihood (LIML) significance-level distortion, in the case of a single endogenous explanatory variable and five instruments. This indicates that the instruments are weakly relevant to predicting Main-bank firm

\footnotetext{
20 Boot and Thakor (2000), Dell'Arriccia and Marquez (2004) and Hauswald and Marquez (2006) offer classical arguments for a positive correlation between competition and relationship lending, while Presbitero and Zazzaro (2009) present evidence for Italy.
} 
relationshi $p^{21}$. When the excluded instruments are valid, but only weakly correlated with the endogenous explanatory variables, the IV estimates are known to be biased in the same direction as OLS (in our case, the bias of estimated IV coefficients is only 50 percent lower than the bias of OLS coefficients), and estimates may not be consistent (Chao and Swanson 2005). Moreover, with weak instruments the IV-estimated standard errors are too small, tests of significance are distorted and confidence intervals are wrong (Andrews and Stock 2005; Murray 2006). Hence in Table 4 we report point estimates, while confidence intervals which are robust on the strengths of instruments are reported in Table 5.

\section{[Insert Table 5]}

As $t$-tests and Wald tests based on the LIML estimator are more robust to weak instruments than those based on the TSLS estimator, i.e., as the maximal size of distortion in significance level for tests is lower in regressions using the former estimator, in Table 4 we report results based on both LIML and TSLS, and p-values from the standard $t$-test and the conditional likelihood ratio (CLR) test proposed by Moreira (2003) ${ }^{22}$. Moreover, as hypothesis testing with weak instruments is especially well developed (and coded in Stata routines by Mikusheva and Poi (2006)) for models with independent identically distributed homoskedastic normal errors, unlike in OLS regressions, we assume that the error term in the structural equation (1) is conditionally homoskedastic ${ }^{23}$.

Albeit with some differences with respect to OLS results, IV estimations tend to validate previous findings. In particular, the non-significance of coefficients of Main-bank relationship length in the whole-sample specifications seems to be driven by the opposite effects that enduring credit relationships with main banks have on small and medium-large enterprises. Even after controlling for omitted variables and endogeneity of the duration of credit relationships, close bank ties prove to be a serious obstacle to the long-run employment growth projects of small firms. The estimated coefficient of Main-bank relationship length is significant at the 5 percent level as in OLS regressions, both using the standard $t$-test and the CLR test (and at the 1 percent level considering the LM test; see Table 5). However, point estimates are much higher than in OLS, especially when we use the LIML estimator, even if the weak-instrument-robust confidence intervals constructed from CLR, AR and LM tests are

\footnotetext{
21 A similar indication of weak instrument problems for the length of the bank relationship is provided by the study of Herrera and Minetti (2007) on the likelihood of firms adopting innovation. However, as they use non-linear TSCML regressions for which tests for weak instruments are not available, they do not provide weak-instrument-robust inference.

${ }^{22}$ Inference on coefficients of Main-bank relationship length based on the Anderson-Rubin (AR) and the LM tests provide similar results (see Table 5). The only differences worth noting with regard to the AR tests are: (i) the non-significant impact of Main-bank relationship length for asset growth of medium-large enterprises; (ii) the rejection at 10.4 percent level of significance of a null correlation between Main-bank relationship length and the average conditional asset-growth rate for the whole sample.

${ }^{23}$ However, results of IV regressions remain practically identical if we compute standard errors robust to heteroskedasticity and abandon weak-instrument-robust inference.
} 
very wide, indicating that the magnitude of coefficients of IV estimations are not very informative. Looking at asset growth, the effect of close bank ties is still negative but, after instrumenting, p-values associated to coefficients are slightly larger than 10 percent.

With regard to medium-large enterprises, IV estimations provide statistically more significant evidence of a positive correlation between an exclusive credit relationship and growth (see columns 912). This is especially true if growth is measured in terms of total assets, suggesting that long-lasting ties with the main bank prove to be helpful to take advantage of (to tackle) unforeseen opportunities (downturns), providing financial flexibility to large enterprises.

Finally, it is worth noting that while the violation of Gibrat's law seems to be confirmed by IV regressions, the coefficient on Age tends to lose statistical significance, and for small firms also assumes a positive $\operatorname{sign}^{24}$.

\section{The effects of long-lasting bank ties on growth rate distribution}

From the previous analysis, we find that the effects of the length of lending relationships on growth rates are opposite for small and large firms: long-lasting bank ties have an adverse, significant impact on the average growth rate of small firms, while they have a favorable or neutral effect on the growth of medium-large firms. However, long-lasting bank ties can produce asymmetric effects also on positive and negative growth of small and large enterprises. For example, conditional on firms' distress, the optimal response policy of relational banks for large and small client firms might differ. If large firms capture banks or if ultimate liquidation is less likely for large borrowers, relational banks could be willing to help distressed borrowers and restrain their downsize only if they are large clients. Vice versa, to the extent that small borrowers that are growing rapidly are also more risky and that the costs they face to switch banks are higher than for large firms, banks can find it optimal to curb their expansion projects, while being willing to support those of large clients.

To test for such possible asymmetric effects, in this section we present results from quantile regressions of small- and large-firms' growth rates. With quantile regressions we can model the entire distribution of firms' growth rates and verify the existence of an asymmetric correlation with Mainbank relationship length at the lower and upper tails of employment or asset growth distribution. If this were the case - and if the troubled firms were concentrated at the lower tail and the healthy firms at the upper tail -, we could gain some evidence on the asymmetry of relationship length effects.

\footnotetext{
24 The change of sign for the coefficient of Age in IV estimations is consistent with results found by Herrera and Minetti (2007). For the sake of robustness, as in the OLS specifications 3-4, 7-8, and 11-12, IV regressions have also been run adding the six further controls described in sub-section 5.1.2, both instrumenting and non-instrumenting the Number of Banks variable. Results on our main variable do not change, especially the negative impact of relationship length upon the growth of small firms.
} 
From the analysis of the unconditional cumulative distribution of employment- and asset-growth rates some interesting results emerge. First, growth distributions are skewed to the right, especially the growth rate of small-firm's employees. In this case, the skewness coefficient is 0.94 , with 34 percent of sampled firms showing a positive growth and a large proportion of observations (44 percent) concentrated at the zero-growth median value. For medium-large firms, 25 percent of the sample experienced zero growth in the three-year survey period, while 28 percent experienced negative growth, 47 percent positive. In the case of growth of firms' asset value, as expected we observed no zerogrowing firms: 61 (60) percent of small (medium-large) firms grew positively while the remaining 39 (40) percent reduced their asset-size.

In Figure 1(A-D) we display quantile regressions results for length of Main-bank relationship and the seven other control variables, with the exclusion of the intercept, area-, industry- and timedummies, where we plot the percentiles of the ordered variable Growth on the horizontal axis and the conditional-on-covariates impact of a one-unit change of the exogenous variable on firms' growth rate on the left vertical scale. In each of the panels we report: (1) the estimated coefficients from the 100 quantile regressions of the 100 percentiles of Growth as the solid line; (2) the conventional 90 percent confidence intervals for quantile coefficients as the shaded gray area; (3) the OLS estimates of the conditional mean effect as the horizontal dashed line; (4) the 90 percent confidence intervals for the mean effect as the two horizontal dotted lines; (5) the unconditional percentiles of the growth rate distribution at which the growth rate becomes zero or positive as the vertical dashed lines.

\subsection{Long-lasting bank ties}

Consider small enterprises first (Figures 1A and 1C). Because of the grand mass of zeros in the central part of the unconditional distribution of the employment-growth rate, for regressions from the $29^{\text {th }}$ to the $57^{\text {th }}$ percentiles we cannot obtain iterative convergence. At lower percentiles, broadly corresponding to small firms growing negatively, enduring main-bank ties are not significantly correlated with firms' growth. By contrast, starting from the $58^{\text {th }}$ percentile, where the growth rate assumes positive values, the effect of long-lasting bank ties becomes negative and statistically significant at the 10, 5 or 1 percent levels ${ }^{25}$. In particular, close bank ties have a negative impact, which is significant at the 10 percent level on almost all the conditional percentiles from the $58^{\text {th }}$ to the $97^{\text {th }}$, and at the 5 percent level for the farthest part of the distribution. Therefore, an increase in Main-bank relationship length causes the upper tail of the conditional distribution of employment growth to shift to the left, which is like saying that, on average, the positive growth rate of small, healthy firms is lower if they have been clients of the

\footnotetext{
${ }^{25}$ Coefficients at the $73^{\text {rd }}$ and $85^{\text {th }}$ percentiles are not significant at the 10 percent level, but at a slightly higher level, while coefficients at the last two percentiles are very large in magnitude but statistically insignificant.
} 
same main bank for a long time. At the same time, if unhealthy, small firms seem not to reduce their downsizing by maintaining long-lasting relationships with the main bank. The adverse effect of longlasting bank ties increases at the higher growth percentiles, reaching, at the $98^{\text {th }}$ percentile, almost six times the average effect found in the OLS estimation.

\section{[Insert Figure 1]}

The asymmetric impact of enduring credit relationships on healthy and unhealthy small-firm growth is broadly confirmed in the quantile regressions of the growth rate of total assets (Panel C). The quantile point estimate of the Main-bank relationship length coefficient is continuously decreasing in magnitude across the percentiles of the conditional asset growth distribution, becoming lower than the OLS estimates of the mean effect after the $63^{\text {th }}$ percentile and with the largest effects on the upper decile (the coefficient is -0.313 at the $97^{\text {th }}$ percentile) ${ }^{26}$. From the $61^{\text {th }}$ and up to the $97^{\text {th }}$ conditional percentiles the negative impact of long-lasting bank ties is statistically significant even at the 1 percent level. However, unlike the case of employment growth, small firms at the very lowest percentiles of asset-growth distribution (that is observations from the $5^{\text {th }}$ up to the $7^{\text {th }}$ percentiles) seem to benefit from the bank relationship, reducing their negative growth.

Figures $1 \mathrm{~B}$ and 1D present quantile coefficients for Main-bank relationship length concerning the medium-large-firm subsample. In this case, consistent with the hypothesis that large, distressed firms with long-lasting ties with a main bank are more likely to find financial support than bank-independent firms, quantile point estimates at the $5^{\text {th }}$ up to the $17^{\text {th }}$ percentiles of employment growth distribution are positive and significant at least at the 10 percent level - where in the unconditional growth distribution firms with average growth rates between -9.1 to -2.6 percent are concentrated - with a coefficient of 0.119 for the $5^{\text {th }}$ percentile, i.e., almost 9 times the OLS coefficient of 0.014 . However, for much of the growth distribution ${ }^{27}$, and for the conditional median, quantile estimates are practically identical to OLS estimates in magnitude and significance, suggesting that the positive growth of medium and large firms is neither hampered nor stimulated by long-lasting relationships with main banks.

When we look at the asset growth rate, Main-bank relationship length does not seem to have any statistically significant impact on its conditional distribution. The sign of estimated coefficients is positive across almost all the percentiles, with a size similar to the OLS estimates of the mean effect, but with a statistical significance always higher than 10 percent.

\subsection{Control variables}

\footnotetext{
${ }^{26}$ In this case, no problem of iterative convergence arises and we obtain point estimates for all the percentiles.

${ }^{27}$ Given the lower number of observations bounded to zero, we can run quantile regression across all the percentiles.
} 
Moving on to the other control variables, we have the confirmation that the determinants of positive and negative firms' growth rates are distinct. This holds especially for the growth of employment and is consistent with the idea that change in the number of workers is a planned project entailing irreversible organizational investments in the very short run and sunk costs. If we look at the small-firm subsample (Figure 1A), Age, Leverage, Export, Group and $R \& D$ have significant effects on the upper tail of the Growth distribution (which includes firms with growth rates greater than zero), but not on its lower tail. By contrast, the variables influencing Growth at the lower percentiles are only Size and Cash-flow, for which quantile coefficients are quite different from those obtained by the conventional OLS confidence intervals. For medium-large firms (Figure 1B), we find similar trends in coefficient significance across percentiles, but in magnitudes quantile point estimates broadly fall within the confidence intervals of OLS estimations.

For the asset-growth rate, quantile results at the lower and upper tails of Growth distribution deviate to a lesser extent from the conditional mean effects of the OLS estimates. For small firms (Figure 1C), it is only Leverage which moves well beyond the least squares, assuming opposite signs at the lower and upper tails of Growth distribution in accordance with the diverse interpretation (firm's riskiness or degree of access to external finance) attributable to this variable. For medium-large firms, besides Leverage, appreciable disparities between quantile and OLS regressions emerge with regard to firms' age, which has a negative impact on Growth only at the upper percentiles, and for firms' belonging to a group, which stimulates both positive and negative asset-growth rate, making Growth distribution more spread around the mean.

\section{Long-lasting bank ties and the likelihood of firms' employment growth or decline}

As clearly testified by many zero-employment-growth firms, the decision to modify the number of employees can be conveniently separated into two conceptually distinct choices: first, the choice of whether to recruit/dismiss personnel (hereafter, the occupational-changing choice); second, how many workers to hire/ fire (the occupational-intensity choice).

\subsection{The occupational-changing choice}

In order to investigate the effects of the length of credit relationships on the occupational-changing choice, we build a new categorical variable, Growth_123, assuming the value of 1 if firms hire workers during the three-year survey period, the value of 2 if firms leave the number of workers unaltered and 3 if firms reduce their employment-size. As the occupational-changing choice has no natural ordering, we 
resort to multinomial logistic regressions to estimate the likelihood of the firm choosing one of the three options.

We assume that each firm $i$ attaches a random utility $U_{i j}=x_{i j}^{\prime} \beta+\varepsilon_{i j}$ to the alternatives $j=1,2,3$ of hiring, maintaining or firing workers. In this case, the likelihood of the firm choosing alternative $j$ is equal to the likelihood of this alternative yielding the maximum utility among all the other alternatives $k \neq j:$

$$
\operatorname{Prob}\left(G r o w t \underline{b 123_{i}}=j\right)=\operatorname{Prob}\left[x_{i j}^{\prime} \beta+\varepsilon_{i j}>\max _{k \neq j}\left(x_{i k}^{\prime} \beta+\varepsilon_{i k}\right)\right]
$$

Assuming that the random terms $\varepsilon_{i j}$ are independent and identically distributed with log-Weibull distribution, we obtain the multinomial logit model (Greene 2003):

$$
\operatorname{Prob}\left({\text { Growth } 123_{i}}_{i}=j\right)=\frac{\exp \left(x_{i j}^{\prime} \beta\right)}{\exp \left(x_{i 1}^{\prime} \beta\right)+\exp \left(x_{i 2}^{\prime} \beta\right)+\exp \left(x_{i 3}^{\prime} \beta\right)}
$$

As (5) makes clear, the independence of $\varepsilon_{i j}$ causes the odds ratio $P_{j} / P_{k}$ to be independent of the other alternatives. For the type of decision we analyze, i.e., whether to change the firms' employment size, the assumption of independence of irrelevant alternatives (the IIA property) does not seem to be very restrictive. When boards are called to decide on the change of firm size it is reasonable to assume that what is at stake is the option to recruit (dismiss) new personnel versus the alternative to continue the business with the same number of employees at the moment of the decision, while the option to dismiss (recruit) workers is irrelevant given the positive-health (distress) conditions of the firm. In confirmation of this conjecture, the Hausman-type test for the IIA property never rejects the null that the parameters from the restricted model obtained by eliminating one alternative from the choice set are not systematically different from parameters from the unrestricted model contemplating all the three growth alternatives (see Table 6$)^{28}$.

\section{[nsert Table 6]}

In Table 6 we report multinomial-logit-regression relative risk ratios using the zero-growth option $($ Growth_123 = 2) as base-choice. The longer the duration of the credit relationship with the main bank, the lower the probability that small firms decide to hire new workers and the lower the probability that medium-large firms decide to dismiss part of their workforce. More specifically, a onestandard-deviation increase in Main-bank relationship length causes an almost 13 percent decrease in the odds that a small firm experiences a positive employment-growth rather than maintaining its size unaltered, while with an identical increase of Main-bank relationship length the odds that a medium-

\footnotetext{
${ }_{28}$ The results reported in Table 6 refer to the generalized version of the Hausman test obtained by using seemingly unrelated estimations (i.e. by using the suest command of Stata).
} 
large firm fires workers rather than maintain their workforce decrease by almost 14 percent. On the contrary, long-lasting bank relationships do not seem to provide small firms with special support when they are in trouble, as a relative risk ratio non-significantly different from 1 in the "negative versus zero growth" specification (column 2) clearly indicates.

In the last part of Table 6 we report the theoretical probability of the average firm increasing, decreasing and maintaining the level of occupation unaltered when the duration of credit relationship with the main bank is equal to, respectively, the $25^{\text {th }}$ and $75^{\text {th }}$ percentiles of its (sub)sample distribution. For the average small firm, such an increase in Main-bank relationship length would reduce by 8.4 percent the probability of hiring new workers (from 0.35 to 0.32 ), while the probability of zero-growth would be 5.6 percent greater ${ }^{29}$. By contrast, the probability of medium-large firms expanding their workforce is broadly the same regardless of the length of credit relationships with the main bank, while the probability of dismissing workers and shrinking their activity would be 10.6 percent lower (decreasing from 0.27 to 0.24 ), to the benefit of an 8.6 percent higher probability of zero-growth (rising from 0.24 to 0.26$)^{30}$.

With regard to the other covariates, it is worth noting that in both sub-samples, the greater the initial firm size the greater the odds that firms experience subsequent changes (either positive or negative) in size, while Age has no significant effect on the odds ratios, except for large firms in the "negative versus zero growth" specification. However, of great importance for occupational-changing choices is cash flow availability. The odds of "positive versus zero growth" rise by 19.2 (29.4) percent by a one-standard-deviation increase of Cash flow for small (medium-large) enterprises, while the odds of "negative versus zero growth" fall by 21.4 (22.3) percent. Finally, the relative risk ratio for Leverage greater than one suggests that, for small firms, access to external financial resources is especially important for pursuing positive employment-growth projects.

\subsection{The occupational-intensity choice}

Maintaining long-lasting ties with a main bank seems to adversely affect the decision to increase employment size by small enterprises, while it seems to support the decision to postpone the firing of workers by medium-large enterprises. But do close bank ties influence the decision on the number of workers to hire or fire, and if so, in what way? In other words, how do enduring credit relationships influence the firms' occupational-intensity choice?

\footnotetext{
${ }^{29}$ With Main-bank relationship length at the $90^{\text {th }}$ percentile, these changes would reach, respectively, -11.3 and 8 percent.

${ }^{30}$ With Main-bank relationship length at the $90^{\text {th }}$ percentile, medium-large firms would decrease (increase) the likelihood of firing (maintaining unaltered the number of) workers by 13.7 (11.3) percent.
} 
Clearly, the simple strategy of splitting the Growth variable and estimating OLS models for the two sub-samples of positively and negatively growing firms would produce biased results if, as is reasonable to assume, the inclusion in the sub-samples is correlated with unobservable explanatory variables that affect the intensity of positive and negative growth (Heckman 1979). To overcome this difficulty, we build two distinct sample selection models where the equation of interest is the intensity of positive and negative employment growth and the selection equations are the binary-choice models for the probability of firms increasing or decreasing occupation. Therefore:

$$
\begin{aligned}
& \text { Growth }=\left\{\begin{array}{ll}
\text { Growth } & \text { if } Z_{1 i t}=1 \\
\text { missing } & \text { if } Z_{1 i t}=0
\end{array} ; \quad \operatorname{Prob}\left(Z_{1 i t}=1 \mid \mathbf{x}_{1 i t}\right)=\Phi\left(\mathbf{x}_{1 i t}^{\prime} \boldsymbol{\delta}_{1}\right)\right. \\
& \text { Growth }_{i t}=\left\{\begin{array}{ll}
\text { Growth } & \text { if } Z_{2 i t}=1 \\
\text { missing } & \text { if } Z_{2 i t}=0
\end{array} ; \quad \operatorname{Prob}\left(Z_{2 i t}=1 \mid \mathbf{x}_{1 i t}\right)=\Phi\left(\mathbf{x}_{1 i t}^{\prime} \boldsymbol{\delta}_{1}\right)\right.
\end{aligned}
$$

where $\Phi(\cdot)$ is the cumulative normal probability function and:

$$
\left\{\begin{array}{l}
Z_{1 i t}=1 \quad \text { if Growth }>0 \\
Z_{1 i t}=0 \quad \text { if Growth } \leq 0
\end{array} ; \quad\left\{\begin{array}{l}
Z_{2 i t}=1 \text { if Growth }<0 \\
Z_{2 i t}=0 \text { if Growth } \geq 0
\end{array} .\right.\right.
$$

Models (6a) and (6b) are estimated with Heckman's two-step procedure. We first estimate the selection equation as a probit on the full sample of small and medium-large enterprises, respectively. Then we estimate the equation of interests by running OLS on the non-missing values of Growtht and Growth $_{i t}$, adding as explanatory the estimated Heckman lambdas, $\hat{\lambda}_{1 i t}=\phi\left(\mathbf{x}_{1 i t}^{\prime} \hat{\boldsymbol{\delta}}_{1}\right) / \Phi\left(\mathbf{x}_{1 i t}^{\prime} \hat{\boldsymbol{\delta}}_{1}\right)$ and $\hat{\lambda}_{2 i t}=\phi\left(\mathbf{x}_{2 i t}^{\prime} \hat{\boldsymbol{\delta}}_{2}\right) / \Phi\left(\mathbf{x}_{2 i t}^{\prime} \hat{\boldsymbol{\delta}}_{2}\right)$, to allow for the possible correlation between the error terms in the growth and selection equations.

Table 7 displays results for the two-step Heckit estimator. As specific regressors for the selection models, we use three dummy variables: (i) Roa which is equal to 1 for firms with a Return on asset ratio greater than zero and 0 otherwise; (ii) Default risk which is 1 for firms whose one-year probability of default is greater than 0.053 (the median value for the whole sample) ${ }^{31}$; (iii) Credit rationing. The idea is that profitability, riskiness - when greater (lower) than a certain threshold - and credit constraints should affect the direction of firms' growth more than its intensity ${ }^{32}$.

[Insert Table 7]

\footnotetext{
31 The one-year probability of default is drawn from the RiskCalc ${ }^{\text {TM }}$ Italy model developed by Moody's KMV (Dwyer et al. 2004). The RiskCalc ${ }^{\mathrm{TM}}$ model for one-year risk of default combines firm's financial statement ratios concerning profitability, leverage, debt coverage, growth, liquidity, activity ratios and size. We thank Toni Riti of Unicredit for kindly providing us with the Default risk variable.

32 It is worth noting that when we include Roa, Default risk and Credit rationing in the least squares regression, they are not significantly associated either with Growth or with Growth . $_{i t}$.
} 
Consistent with multinomial logit findings, the estimations for the selection mechanisms clearly indicate that the longer the credit relationship with the main bank, the lower the probability that a small firm falls within the sample of firms that increase their employment-size (the coefficient for Main-bank relationship length is significantly negative at the 1 percent level) and that a large firm dismisses workers (even though in this case the estimated coefficient is significant only at the 10 percent level). By contrast, the effects of long-lasting bank ties on the likelihood of small firms decreasing and medium-large firms increasing their occupation are no different from zero.

Moving on to the occupational-intensity choice, first of all it is worth noting that the inverse Mill's ratios are no significantly different from zero, suggesting that there may not be any correlation between the unobserved determinants of the propensity to grow, positively or negatively $\left(Z_{1 i t}\right.$ and $\left.Z_{2^{i t}}\right)$, and unobserved determinants of Growth and Growthit ${ }^{33}$. Second, the coefficient for Main-bank relationship length is statistically significant only in the case of the positive growth of small firms and with a negative sign. For the negative growth of medium-large firms the effect of long-lasting bank ties with the main bank is positive, but the p-value is at the 61 percent level of significance.

\section{Conclusions}

A puzzling but consistent result in the empirical literature on banking is that firms with close bank ties do not grow faster than bank-independent firms. In this paper, we reconsider the link between relationship lending and firms' growth, distinguishing firms by size and health. The idea is that the beneficial effects of relationship lending on information asymmetries can be compensated by other negative capture, risk and externality effects which make relational banks reluctant to support long-term growth projects of client firms, and that the strength of these compensating effects varies with firm size and health status.

We provided empirical support for this conjecture by looking at the effects that long-lasting ties with the main bank have on firms' employment and asset growth rates. Our main findings can be summarized as follows. Small firms maintaining a stable credit relationship with a main bank grow less, on average, than bank-independent small firms. This is especially true for small healthy firms, while for unhealthy ones maintaining stable relationships with a main bank does not restrain their decline in employment and asset size. With regard to medium-large firms, regression results indicate almost the opposite. On average, long-lasting bank ties have a modest impact on growth performance of mediumlarge firms. However, the probability that medium-large firms, when in trouble, reduce their size

\footnotetext{
${ }^{33}$ It is worth noting that the insignificance of Mill's ratio also corroborates the idea that the occupational-changing and occupational-intensity choices are mutually independent.
} 
permanently by dismissing part of their workforce is significantly lower if they have long-lasting credit ties with a main bank. 


\section{References}

Agarwal R. and J.A. Elston (2001), "Bank-Firm Relationships, Financing and Firm Performance in Germany", Economic Letters, 72, 225-232.

Alessandrini P., A.F. Presbitero and A. Zazzaro A. (2009a), “Banks, Distances and Firms' Financing Constraints", Review of Finance, 13(2), 261-307.

Alessandrini P., A.F. Presbitero and A. Zazzaro A. (2010), "Banks Size or Distance: What Hampers Innovation Adoption by SMEs?”, Journal of Economic Geography, forthcoming .

Andrews D.W.K. and J.H. Stock (2005), "Inference with Weak Instruments", Cowles Foundation Discussion Paper No. 1530.

Angelini P., R. Di Salvo and G. Ferri (1998), "Availability and Cost of Credit for Small Business: Customer Relationships and Credit Cooperatives", Journal of Banking and Finance, 22, 925-954.

Barone G., R. Felici and Pagnini (2006), "Switching costs in local credit markets", paper presented at the Conference "The changing geography of banking" (Ancona - Italy), downloadable at http://geographybanking.univpm.it/pdf/82.pdf

Becchetti L. and G. Trovato (2002), “The Determinants of Growth for Small and Medium Sized Firms. The Role of the Availability of External Finance", Small Business Economics, 19, 291-306.

Berger A.N. and G. Udell (1995), "Relationship Lending and Lines of Credit in Small Firm Finance", Journal of Business, 3, 351-381.

Bharath S., S. Dahiya, A. Saunders and A. Srinivasan (2007), "So What do I Get? The Bank's View of Lending Relationships", Journal of Financial Economics, 85, 368-419.

Bharath S., S. Dahiya, A. Saunders and A. Srinivasan (2009), "Lending Relationships andLoan Contract Terms", Review of Financial Studies, forthcoming.

Boot A. (2000), "Relationship Banking: What Do We Know?”, Journal of Financial Intermediation, 9 , $7-25$.

Boot A. and A. Thakor (2000), “Can Relationship Banking Survive Competition?”, Journal of Finance, $55,679-713$.

Brunner A. and J.P. Krahnen (2008), "Multiple Lenders and Corporate Distress: Evidence on Debt Restructuring", Review of Economic Studies, 75(2), 415-442.

Carpenter R. and B. Petersen (2002), "Is the Growth of Small Firms Constrained by Internal Finance?", Review of Economics and Statistics, 84, 298-309.

Chakraborty A. and C.X. Hu (2006), "Lending Relationships in Line-of-Credit and Nonline-of-Credit Loans: Evidence from Collateral Use in Small Business," Journal of Financial Intermediation, 15(1), 86-107. 
Chao J.C. and N.R. Swanson (2005), "Consistent Estimation with a Large Number of Weak Instruments", Econometrica, 73, 1673-1692.

Chirinko R. and J.A. Elston (2006), "Finance, Control and Profitability: the Influence of German Banks", Journal of Economic Behaviour \& Organization, 59, 69-88.

Cole R.A. (1998), “The Importance of Relationships to the Availability of Credit”, Journal of Banking and Finance, 22, 227-251.

Degryse H. and S. Ongena (2001), "Bank Relationships and Firm Profitability", Financial Management, 30, 9-34.

Degryse H. and P. Van Cayseele (2000), "Relationship Lending within a Bank-Based System: Evidence from European Small Business Data", Journal of Financial Intermediation, 9, 90-109.

Dell'Ariccia G. and R. Marquez (2004) "Information and bank credit allocation", Journal of Financial Economics, 72(1), 185-214.

Dewatripont M. E. Maskin (1995), "Credit and Efficiency in Centralized and Decentralized Economies", Review of Economic Studies 62(4), 541-555.

Dunne P. and A. Hughes (1994), "Age, Size, Growth and Survival: UK Companies in the 1980s", Journal of Industrial Economics, 42, 115-140.

Dunne T., Roberts M.J., Samuelson L. (1989), "The Growth and Failure of Manufacturing Plants", Quarterly Journal of Economics, 104, 671-698.

Dwyer D.W., A.E. Kocagil and R.M. Stein (2004), “The Moody’s KMV EDF RiskCalc v3.1 Model: Next Generation technology for Predicting Private Firm Risk, Moody’s KMV Company:USA.

Elsas R. (2005), "Empirical Determinants of Relationship Lending”, Journal of Financial Intermediation, 14 , pp. 32-57.

Elston J.A. (2002), “An Examination of the Relationship Between Firm Size, Growth, and Liquidity in the Neuer Market", Economic Research Center of the Deutsche Bundesbank Discussion Paper Series No. 15.

Evans D.S. (1987), "The Relationship between Firm Growth, Size and Age: Estimates for 100 Manufacturing Industries", Journal of Industrial Economics, 35, 567-581.

Fok R.C., Y.C. Chang Y.C. and W.T. Lee (2004), "Bank Relationships and Their Effects on Firm Performance around the Asian Financial Crisis: Evidence from Taiwan”, Financial Management, 33, 89-112.

Greene W.H. (2003), Econometric Analysis, New York: New York University.

Grunert J. and L. Norden (2009), "Bargaining Power and Information in SME Lending”, mimeo. 
Guiso L., P. Sapienza and L. Zingales (2004a), "Does Local Financial Development Matter?”, Quarterly Journal of Economics 119, 929-969.

Guiso L., P. Sapienza and L. Zingales (2004b), "The Role of the Social Capital in Financial Development", American Economic Review, 94, 526-556.

Hall B.H. (1987), "The Relationship between Firm Size and Firm Growth in the US. Manufacturing Sector", Journal of Industrial Economics, 35, 583-606.

Harhoff D. and T. Körting (1998), "Lending Relationships in Germany- Empirical Evidence from Survey Data“, Journal of Banking and Finance, 22, 1317-1353.

Hauswald R. and R. Marquez (2006), "Competition and Strategic Information Acquisition in Credit Markets", Review of Financial Studies, 19, 967-1000.

Heckman J. (1979) "Sample Selection Bias as a Specification Error", Econometrica, 47, 153-161.

Herrera A.M. and R. Minetti (2007), "Informed Finance and Technological Change: Evidence from Credit Relationships", Journal of Financial Economics, 83, 223-269.

Hernandez G. and P. Martinez (2006), "Banking Relationships: Effects on the Debt Terms for Small Spanish Firms", Journal of Small Business Management, 44, 315-333.

Heshmati A. (2001), "On the Growth of Micro and Small Firms: Evidence from Sweden", Small Business Economics, 17, 213-228.

Honjo Y. and N. Harada (2006), "SME Policy, Financial Structure and Firm Growth: Evidence from Japan”, Small Business Economics, 27, 289-300.

Hoshi T., A. Kashyap, D. Scharfstein (1990), "The Role of Banks in Reducing Financial Distress in Japan”, NBER Working Paper no. 3435.

Houston J.F. and C.M. James (2001), “Do Relationships Have Limits? Banking Relationships, Financial Constraints and Investment", Journal of Business, 74, 347-374.

Ijiri Y. and H.A. Simon (1977), Skew Distribution and the Size of Business Firms, Amsterdam: NorthHolland.

Ioannidou V. and S. Ongena (2010), "'Time for a Change": Loan Conditions and Bank Behavior when Firms Switch Banks" Journal of Finance, forthcoming.

Jappelli T., M. Pagano M. and M. Bianco (2005), "Courts and Banks: Effects of Judicial Enforcement on Credit Markets", Journal of Money, Credit and Banks, 37, 223-244.

Jensen M.C. and W.H. Meckling (1976), "Theory of the Firm: Managerial Behavior, Agency Costs and Ownership Structure", Journal of Financial Economics, 3, 305-60.

Jiménez G., J.A. Lopez ans J. Saurina (2009), "Empirical Analysis of Corporate Credit Lines”, Review of Financial Studies, forthcoming. 
Johnson S.H., R. La Porta, F. Lopez de Silanes and A. Shleifer (2000), "Tunnelling", American Economic Review Papers and Proceedings, 90(2), 22-27.

Jovanovic B. (1982), "Selection and Evolution of Industry", Econometrica, 50, pp. 649-670.

Kawai M., J. Hashimoto and S. Izumida (1996), "Japanese Firms in Financial Distress and Main Banks: Analyses of Interest-Rate Premia", Japan and the World Economy, 8, 175-194.

Kang J.-K. and A. Shivdasani (1997), "Corporate Restructuring During Performance Declines in Japan”, Journal of Financial Economics, 46, 29-65.

Lang L., E. Ofek and R.M. Stulz (1996), "Leverage, Investment and Firm Growth", Journal of Financial Economics, 40, 3-29.

Longhofer S.D. and J.A.C. Santos (2000), "The Importance of Bank Seniority for Relationship Lending", Journal of Financial Intermediation, 9, 57-89.

Miarka T. (1999), The recent economic role of bank-firm relationships in Japan, Wissenschaftszentrum Berlin.

Mikusheva A. and B.P. Poi (2006), "Tests and Confidence Sets with Correct Size When Instruments are Potentially Weak", The Stata Journal, 6, pp. 335-347.

Montoriol Garriga J. (2006), “The Effect of Relationship Lending on Firm Performance”, Universitat Autònoma de Barcelona Documents de Treball No. 06/5.

Moreira M. (2003) “A Conditional Likelihood Ratio Test for Structural Models", Econometrica, 71, 1027-48.

Murray M.P. (2006), “Avoiding Invalid Instruments and Coping with Weak Instruments”, Journal of Economic Perspectives, 20, 111-132.

Myers S. and N. Majluf (1984), "Corporate Financing Decisions when Firms Have Investment Information that Investors Do Not", Journal of Financial Economics, 13, 187-220.

Nakatani I. (1984), “The Role of Financial Corporate Grouping”, in M. Aoki (ed), Economic Analysis of the Japanese Firm, New York: North-Holland.

OECD (2004), Employment Outlook, Paris.

Ogawa K., E. Sterken and I. Tokutsu (2007), "Why do Japanese Firms Prefer Multiple Bank Relationship? Some Evidence from Firm-Level Data", Economic Systems, 31, 49-70.

Oliveira B. and A. Fortunato (2006), "Firm Growth and Liquidity Constraints: A Dynamic Analysis", Small Business Economics, 27, 139-156.

Ono A. and I. Uesugi (2005), The Role of Collateral and Personal Guarantees in Relationship Lending: Evidence from Japan’s Small Business Loan Market. RIETI Discussion Paper Series 05-E-027. 
Ongena S. and D. Smith (2001), "The Duration of Bank Relationships", Journal of Financial Economics, 61, 449-475.

Opler T. and S. Titman (1994), "Financial Distress and Corporate Performance", Journal of Finance, 49, 1015-1040.

Peek J. and E.S. Rosengren (2005), "Unnatural Selection: Perverse Incentives and the Misallocation of Credit in Japan," American Economic Review, 95, 1144-1166.

Petersen M.A. and R.G. Rajan (1994), “The Benefits of Lending Relationships: Evidence from Small Business Data", Journal of Finance, 49, 3-37.

Petersen M.A. and R.G. Rajan (1995), "The Effect of Credit Market Competition on Lending Relationships", Quarterly Journal of Economics, 110, 406-443.

Presbitero A.F. and A. Zazzaro (2009), "Competition and Relationship Lending: Friends or Foes?" Mo.Fi.R. Working Paper no. 8/09.

Rajan R.G. (1992), "Insiders and Outsiders: The Choice between Informed and Arm's-Length Debt", Journal of Finance, 47, 1367-1400.

Rajan R.G., H. Servaes H. and L. Zingales (2000), "The Cost of Diversity: The Diversification Discount and Inefficient Investment," Journal of Finance, 55(1), 35-80.

Ross S. (1977), “The Determination of Financial Structure: The Incentive-Signaling Approach”, Bell Journal of Economics, 8, 23-40.

Sharpe S.A. (1990), “Asymmetric Information, Bank Lending and Implicit Contracts: A Stylized Model of Customer Relationships”, Journal of Finance, 45, 1069-1087.

Sakai, K., I. Uesugi I. and T. Watanabe (2005), "Firm Age and the Evolution of Borrowing Costs: Evidence from Japanese Small Firms”, RIETI Discussion Paper Series 05-E-026.

Shin H.G. and J.W. Kolari (2004), "Do Some Lenders Have Information Advantages? Evidence from Japanese Credit Market Data”, Journal of Banking and Finance, 28, 2321-2351.

Stock J.H. and M. Yogo (2005), Testing for Weak Instruments in Linear IV Regression, in D.W.K. Andrews, and J.H. Stock (eds), Identification and Inference for Econometric Models: Essays in Honor of Thomas Rothenberg, Cambridge: Cambridge University Press, 80-108.

Stulz R.M. (1990), "Managerial Discretion and Optimal Financing Policies", Journal of Financial Economics, 26, 3-27.

Sutton J. (1997), “Gibrat's Legacy”, Journal of Economic Literature, 35(1), 40-59.

Weinstein D. and Y. Yafeh (1998), "On the Costs of a Bank-Centered Financial System: Evidence from the Changing Main Bank Relations in Japan”, Journal of Finance, 53, 635-672. 
Williamson O. (1976), "Franchise Bidding for Natural Monopolies - In General and With Respect to CATV", Bell Journal of Economics, 7, 73-104.

Williamson O. (1985), The Economic Institutions of Capitalism, New York: Free Press.

Yafeh Y. and O. Yosha (2003), "Large Shareholders and Banks: Who Monitors and How?” Economic Journal, 113, 128-146. 
Table 1. Variables and sources.

\begin{tabular}{|c|c|c|}
\hline Variables & Definitions & Sources \\
\hline Growth & $\begin{array}{l}\text { Employment or assets average annual rate of growth computed as the difference between the } \\
\text { logarithms of the respective levels over the length of the period. }\end{array}$ & Unicredit-Capitalia Surveys \\
\hline Duration & Credit length minus 3 if credit length is greater than 3 and 0 if credit length is less than or equal to 3 . & Unicredit-Capitalia Surveys \\
\hline $\begin{array}{l}\text { Main-bank relationship } \\
\text { length }\end{array}$ & Natural logarithm of $(1+$ Duration $)$ divided by 10 & Unicredit-Capitalia Surveys \\
\hline Size & $\begin{array}{l}\text { Natural logarithm of the number of employees or total assets (measured in euro at constant prices of } \\
\text { 1995). }\end{array}$ & Unicredit-Capitalia Surveys \\
\hline Age & $\begin{array}{l}\text { Natural logarithm of } 1 \text { plus the age of the firm computed as the year of the survey minus the year of } \\
\text { inception. }\end{array}$ & Unicredit-Capitalia Surveys \\
\hline Cash flow & Cash flow over total assets. Cash flow computed as ordinary profits plus depreciation. & Unicredit-Capitalia Surveys \\
\hline Leverage & Leverage ratio computed as debt over total assets. & Unicredit-Capitalia Surveys \\
\hline Export & Dummy that takes the value of 1 if firm exports and 0 otherwise. & Unicredit-Capitalia Surveys \\
\hline Group & Dummy that takes the value of 1 if firm belongs to a group and 0 otherwise. & Unicredit-Capitalia Surveys \\
\hline$R \& D$ & Dummy that takes the value of 1 if firm had R\&D expenditures and 0 otherwise. & Unicredit-Capitalia Surveys \\
\hline$M \& A$ & $\begin{array}{l}\text { Dummy that takes the value of } 1 \text { if the firm took over or merged with other firms in the three-year } \\
\text { period and } 0 \text { otherwise. }\end{array}$ & Unicredit-Capitalia Surveys \\
\hline$H H I$ & Herfindahl-Hirschman Index calculated, by province, on the number of branches (divided by 1000). & Bank of Italy \\
\hline Local bank & $\begin{array}{l}\text { Dummy that takes the value of } 1 \text { if the firm and its main bank are headquartered in the same } \\
\text { province and } 0 \text { otherwise. }\end{array}$ & Unicredit-Capitalia Surveys \\
\hline Branches & $\begin{array}{l}\text { Number of banks' branches in the province where the firm is headquartered, per } 10000 \text { inhabitants, } \\
\text { in } 1936 .\end{array}$ & Bank of Italy \\
\hline Cooperative banks & $\begin{array}{l}\text { Share of branches held by credit cooperative banks in the province where the firm is headquartered, } \\
\text { in } 1936 .\end{array}$ & Bank of Italy \\
\hline Saving banks & Share of branches held by saving banks in the province where the firm is headquartered, in 1936. & Bank of Italy \\
\hline New branch entrants & $\begin{array}{l}\text { Average number of branches created by entrants in the province where the firm is headquartered in } \\
1991-1998 \text { (divided by 1000). }\end{array}$ & Bank of Italy \\
\hline New branch incumbents & $\begin{array}{l}\text { Average number of branches created by incumbents in the province where the firm is headquartered } \\
\text { in 1991-1998 (divided by 1000). }\end{array}$ & Bank of Italy \\
\hline Roa & $\begin{array}{l}\text { Dummy that takes the value of } 1 \text { for firms with a return on assets ratio greater than } 0 \text {, and } 0 \\
\text { otherwise. }\end{array}$ & Unicredit-Capitalia Surveys \\
\hline Default risk & $\begin{array}{l}\text { Dummy that takes the value of } 1 \text { for firms whose one-year probability of default is greater than } \\
0.053 \text { (the median value for the whole sample) an } 0 \text { otherwise. }\end{array}$ & Unicredit-Capitalia Surveys \\
\hline Credit rationing & $\begin{array}{l}\text { Dummy that takes the value of } 1 \text { if the firm reports it has sought more credit at the interest rate } \\
\text { agreed with the bank and } 0 \text { otherwise. }\end{array}$ & Unicredit-Capitalia Surveys \\
\hline Number of banks & Number of bank relationships held by the firm at the end of the three-year period. & Unicredit-Capitalia Surveys \\
\hline
\end{tabular}


Table 2. Summary statistics by firm size.

\begin{tabular}{|c|c|c|c|c|c|c|}
\hline \multirow[b]{2}{*}{ Variables } & \multicolumn{3}{|c|}{$\begin{array}{c}\text { Small business } \\
(<50 \text { employees } \& \text { total assets } \leq € 5 \\
\text { million })\end{array}$} & \multicolumn{3}{|c|}{$\begin{array}{c}\text { Medium-large business } \\
(\geq 50 \text { employees or total assets }>€ 5 \\
\text { million) }\end{array}$} \\
\hline & Obs. & Mean & Std. Dev. & Obs. & Mean & Std. Dev. \\
\hline Growth (employment) & 2,478 & 0.012 & 0.079 & 2,962 & 0.014 & 0.085 \\
\hline Growth (assets) & 2,470 & 0.0430 & 0.135 & 2,939 & 0.032 & 0.124 \\
\hline Duration & 2,478 & 13.299 & 10.500 & 2,962 & 15.260 & 12.871 \\
\hline $\begin{array}{l}\text { Duration | Growth empl. } \\
>0\end{array}$ & 848 & 11.724 & 9.725 & 1,402 & 15.083 & 12.618 \\
\hline $\begin{array}{l}\text { Duration } \mid \text { Growth empl. }= \\
\end{array}$ & 1,093 & 13.831 & 10.521 & 741 & 15.352 & 12.318 \\
\hline $\begin{array}{l}\text { Duration | Growth empl. } \\
<0\end{array}$ & 537 & 14.704 & 11.317 & 819 & 15.479 & 13.771 \\
\hline $\begin{array}{l}\text { Duration } \mid \text { Growth assets }> \\
0\end{array}$ & 1,506 & 12.677 & 10.086 & 1,774 & 15.244 & 12.796 \\
\hline $\begin{array}{l}\text { Duration } \mid \text { Growth assets }< \\
0\end{array}$ & 964 & 14.295 & 11.070 & 1,165 & 15.298 & 13.054 \\
\hline $\begin{array}{l}\text { Main-bank relationship } \\
\text { length }\end{array}$ & 2,478 & 0.235 & 0.088 & 2,962 & 0.240 & 0.100 \\
\hline Size (employment in levels) & 2,478 & 22.013 & 8.620 & 2,962 & 147.430 & 396.259 \\
\hline $\begin{array}{l}\text { Size (employment in } \\
\text { logarithms) }\end{array}$ & 2,478 & 3.021 & 0.370 & 2,962 & 4.358 & 0.957 \\
\hline Size (assets in levels) & 2,470 & $1,506,359$ & 955,175 & 2,939 & $24,500,000$ & $90,500,000$ \\
\hline Size (assets in logarithms) & 2,470 & 14.027 & 0.645 & 2,939 & 16.189 & 1.049 \\
\hline Age (in levels) & 2,478 & 23.734 & 15.974 & 2,962 & 30.398 & 20.133 \\
\hline Age (in logarithms) & 2,478 & 2.987 & 0.607 & 2,962 & 3.217 & 0.653 \\
\hline Cash flow & 2,478 & 0.065 & 0.056 & 2,962 & 0.067 & 0.053 \\
\hline Leverage & 2,478 & 0.679 & 0.181 & 2,962 & 0.659 & 0.176 \\
\hline Export & 2,478 & 0.600 & 0.490 & 2,962 & 0.828 & 0.377 \\
\hline Group & 2,478 & 0.103 & 0.304 & 2,962 & 0.372 & 0.483 \\
\hline$R \& D$ & 2,478 & 0.300 & 0.458 & 2,962 & 0.540 & 0.499 \\
\hline$M \& A$ & 2,415 & 0.041 & 0.197 & 2,880 & 0.143 & 0.350 \\
\hline$H H I$ & 2,415 & 1.115 & 0.463 & 2,880 & 1.105 & 0.506 \\
\hline Local bank & 2,415 & 0.631 & 0.483 & 2,880 & 0.566 & 0.496 \\
\hline Branches & 2,478 & 2.044 & 0.807 & 2,962 & 2.007 & 0.852 \\
\hline Cooperative banks & 2,478 & 0.158 & 0.142 & 2,962 & 0.164 & 0.138 \\
\hline Saving banks & 2,478 & 0.207 & 0.134 & 2,962 & 0.193 & 0.131 \\
\hline New branch entrants & 2,478 & 0.008 & 0.007 & 2,962 & 0.008 & 0.007 \\
\hline New branch incumbents & 2,478 & 0.020 & 0.023 & 2,962 & 0.021 & 0.023 \\
\hline Roa & 2,158 & 0.873 & 0.334 & 2,628 & 0.840 & 0.367 \\
\hline Default risk & 2,158 & 0.506 & 0.500 & 2,628 & 0.449 & 0.497 \\
\hline Credit rationing & 2,415 & 0.187 & 0.390 & 2,880 & 0.130 & 0.337 \\
\hline Number of banks & 2,415 & 4.092 & 2.102 & 2,880 & 6.868 & 3.903 \\
\hline Fail & 2,415 & 2,570 & 374.524 & 2,880 & 2,646 & 390.401 \\
\hline
\end{tabular}

Obs. =Observations, Std. Dev.= standard deviation.

Note: Assets are measured in euro. Statistics are computed on the sample used in the regression analysis. 
Table 3. Determinants of firms' growth. OLS results.

The table reports $O L S$ regression coefficients and associated p-values. The dependent variable in columns (1), (3), (5), (7), (9) and (11) is the employment percentage rate of growth computed as the difference between the logarithms of the respective levels over the length of the period. The dependent variable in columns (2), (4), (6), (8), (10) and (12) is the assets percentage rate of growth computed as the difference between the logarithms of the respective levels over the length of the period. We measure relationship length with the main bank as the logarithm of 1 plus the number of years with the main bank minus 3 (divided by 10). Size is the logarithm of the number of employees at the beginning of the period. Age is the logarithm of the number of years since the inception of the firm. Cash flow is the ratio of cash flow to total assets. Leverage is the ratio of debt to total assets. The $(0,1)$ notation means the variable is a dummy taking the value of 1 if the firm presents the specified characteristic and 0 otherwise. In order to check for robustness in columns $(3)$, (4), (7), (8), (11) and (12) six additional control variables are added to the basic regression: M\&A, HHI, Local bank, Credit rationing, Number of banks, Fail controlling for external growth through mergers and acquisitions, the concentration of the local credit market, the localism of the main bank, credit rationing, multiple lending and judicial efficiency in bankruptcy trials respectively. All regressions include industrial, geographic and time dummies. ***, ** and * indicate statistically significant at the $1 \%, 5 \%$ and $10 \%$ level, respectively. The table also reports, as a goodness-of-fit test, the p-values of the $F$-statistic for the Wald test of joint significance of regressors.

\begin{tabular}{|c|c|c|c|c|c|c|c|c|c|c|c|c|}
\hline & \multicolumn{4}{|c|}{ Panel A: whole sample } & \multicolumn{4}{|c|}{ Panel B: small business } & \multicolumn{4}{|c|}{ Panel C: medium-large business } \\
\hline & $\begin{array}{c}\text { Empl. } \\
\text { (1) }\end{array}$ & $\begin{array}{c}\text { Assets } \\
(2)\end{array}$ & $\begin{array}{c}\text { Empl. } \\
(3)\end{array}$ & $\begin{array}{c}\text { Assets } \\
\text { (4) }\end{array}$ & $\begin{array}{c}\text { Empl. } \\
(5)\end{array}$ & $\begin{array}{c}\text { Assets } \\
(6)\end{array}$ & $\begin{array}{c}\text { Empl. } \\
(7)\end{array}$ & $\begin{array}{c}\text { Assets } \\
(8)\end{array}$ & $\begin{array}{c}\text { Empl. } \\
(9)\end{array}$ & $\begin{array}{c}\text { Assets } \\
(10)\end{array}$ & $\begin{array}{c}\text { Empl. } \\
(11)\end{array}$ & $\begin{array}{c}\text { Assets } \\
\text { (12) }\end{array}$ \\
\hline \multicolumn{13}{|l|}{ Relationship-banking } \\
\hline Main-bank relationship length & $\begin{array}{l}-0.007 \\
(0.598)\end{array}$ & $\begin{array}{l}-0.024 \\
(0.258)\end{array}$ & $\begin{array}{l}-0.001 \\
(0.980)\end{array}$ & $\begin{array}{l}-0.017 \\
(0.413)\end{array}$ & $\begin{array}{c}-0.044 * * \\
(0.041)\end{array}$ & $\begin{array}{c}-0.079 * * \\
(0.037)\end{array}$ & $\begin{array}{c}-0.042 * * \\
(0.048)\end{array}$ & $\begin{array}{l}-0.072^{*} \\
(0.057)\end{array}$ & $\begin{array}{c}0.014 \\
(0.385)\end{array}$ & $\begin{array}{c}0.010 \\
(0.697)\end{array}$ & $\begin{array}{c}0.024 \\
(0.146)\end{array}$ & $\begin{array}{c}0.017 \\
(0.464)\end{array}$ \\
\hline \multicolumn{13}{|l|}{$\underline{\text { Controls }}$} \\
\hline Size & $\begin{array}{c}-0.009^{* * *} \\
(0.000)\end{array}$ & $\begin{array}{c}-0.011 * * * \\
(0.000)\end{array}$ & $\begin{array}{c}-0.013 * * * \\
(0.000)\end{array}$ & $\begin{array}{c}-0.018^{* * *} \\
(0.000)\end{array}$ & $\begin{array}{c}-0.036 * * * \\
(0.000)\end{array}$ & $\begin{array}{c}-0.029 * * * \\
(0.000)\end{array}$ & $\begin{array}{c}-0.038^{* * *} \\
(0.000)\end{array}$ & $\begin{array}{c}-0.038^{* * *} \\
(0.000)\end{array}$ & $\begin{array}{c}-0.014 * * * \\
(0.000)\end{array}$ & $\begin{array}{c}-0.019 * * * \\
(0.000)\end{array}$ & $\begin{array}{c}-0.017 * * * \\
(0.000)\end{array}$ & $\begin{array}{c}-0.025^{* * *} \\
(0.000)\end{array}$ \\
\hline Age & $\begin{array}{c}-0.008^{* * *} * \\
(0.000)\end{array}$ & $\begin{array}{c}-0.011 * * * \\
(0.002)\end{array}$ & $\begin{array}{c}-0.008 * * * \\
(0.000)\end{array}$ & $\begin{array}{c}-0.014 * * * \\
(0.000)\end{array}$ & $\begin{array}{c}-0.007 * * \\
(0.028)\end{array}$ & $\begin{array}{c}-0.019 * * * \\
(0.001)\end{array}$ & $\begin{array}{c}-0.007 * * \\
(0.026)\end{array}$ & $\begin{array}{c}-0.022 * * * \\
(0.000)\end{array}$ & $\begin{array}{c}-0.008 * * * \\
(0.003)\end{array}$ & $\begin{array}{l}-0.006 \\
(0.180)\end{array}$ & $\begin{array}{c}-0.008 * * * \\
(0.002)\end{array}$ & $\begin{array}{c}-0.008^{* *} \\
(0.039)\end{array}$ \\
\hline Cash flow & $\begin{array}{c}0.237 * * * \\
(0.000)\end{array}$ & $\begin{array}{c}0.282^{* * *} \\
(0.000)\end{array}$ & $\begin{array}{c}0.241 * * * \\
(0.000)\end{array}$ & $\begin{array}{c}0.307 * * * \\
(0.000)\end{array}$ & $\begin{array}{c}0.188^{* * * *} \\
(0.000)\end{array}$ & $\begin{array}{c}0.190^{* * *} \\
(0.000)\end{array}$ & $\begin{array}{c}0.193 * * * \\
(0.000)\end{array}$ & $\begin{array}{c}0.210^{* * *} \\
(0.000)\end{array}$ & $\begin{array}{c}0.289^{* * *} \\
(0.000)\end{array}$ & $\begin{array}{c}0.356^{* * * *} \\
(0.000)\end{array}$ & $\begin{array}{c}0.290^{* * *} \\
(0.000)\end{array}$ & $\begin{array}{c}0.385^{* * *} \\
(0.000)\end{array}$ \\
\hline Leverage & $\begin{array}{c}0.052^{* * *} \\
(0.000)\end{array}$ & $\begin{array}{c}0.027^{* *} \\
(0.015)\end{array}$ & $\begin{array}{c}0.045^{* * *} \\
(0.000)\end{array}$ & $\begin{array}{c}0.005 \\
(0.651)\end{array}$ & $\begin{array}{c}0.053 * * * \\
(0.000)\end{array}$ & $\begin{array}{c}0.019 \\
(0.259)\end{array}$ & $\begin{array}{c}0.048^{* * *} \\
(0.000)\end{array}$ & $\begin{array}{l}-0.007 \\
(0.695)\end{array}$ & $\begin{array}{c}0.046^{* * *} \\
(0.000)\end{array}$ & $\begin{array}{c}0.032 * * \\
(0.033)\end{array}$ & $\begin{array}{c}0.038 * * * \\
(0.000)\end{array}$ & $\begin{array}{c}0.010 \\
(0.505)\end{array}$ \\
\hline Export $(0,1)$ & $\begin{array}{c}0.009^{* * *} \\
(0.001)\end{array}$ & $\begin{array}{c}0.021 * * * \\
(0.000)\end{array}$ & $\begin{array}{c}0.007 * * * \\
(0.003)\end{array}$ & $\begin{array}{c}0.022^{* * *} \\
(0.000)\end{array}$ & $\begin{array}{c}0.007 * * \\
(0.042)\end{array}$ & $\begin{array}{c}0.020^{* * *} \\
(0.001)\end{array}$ & $\begin{array}{l}0.006^{*} \\
(0.073)\end{array}$ & $\begin{array}{c}0.020^{* * *} \\
(0.001)\end{array}$ & $\begin{array}{l}0.007^{*} \\
(0.055)\end{array}$ & $\begin{array}{c}0.017 * * \\
(0.023)\end{array}$ & $\begin{array}{c}0.006 \\
(0.111)\end{array}$ & $\begin{array}{c}0.018^{* * *} \\
(0.009)\end{array}$ \\
\hline Group $(0,1)$ & $\begin{array}{c}0.011 * * * \\
(0.000)\end{array}$ & $\begin{array}{c}0.003 \\
(0.571)\end{array}$ & $\begin{array}{c}0.007^{* *} \\
(0.014)\end{array}$ & $\begin{array}{c}0.001 \\
(0.856)\end{array}$ & $\begin{array}{c}0.010^{* *} \\
(0.045)\end{array}$ & $\begin{array}{c}0.010 \\
(0.338)\end{array}$ & $\begin{array}{l}0.009 * \\
(0.074)\end{array}$ & $\begin{array}{c}0.006 \\
(0.538)\end{array}$ & $\begin{array}{c}0.009 * * \\
(0.017)\end{array}$ & $\begin{array}{c}0.002 \\
(0.647)\end{array}$ & $\begin{array}{c}0.004 \\
(0.221)\end{array}$ & $\begin{array}{c}0.001 \\
(0.798)\end{array}$ \\
\hline$R \& D(0,1)$ & $\begin{array}{c}0.009 * * * \\
(0.000)\end{array}$ & $\begin{array}{c}0.017 * * * \\
(0.000)\end{array}$ & $\begin{array}{c}0.006^{* *} \\
(0.015)\end{array}$ & $\begin{array}{c}0.014 * * * \\
(0.000)\end{array}$ & $\begin{array}{c}0.012 * * * \\
(0.001)\end{array}$ & $\begin{array}{c}0.022^{* * *} \\
(0.000)\end{array}$ & $\begin{array}{c}0.009^{* *} \\
(0.012)\end{array}$ & $\begin{array}{c}0.020^{* * *} \\
(0.000)\end{array}$ & $\begin{array}{l}0.005 \\
(0.124)\end{array}$ & $\begin{array}{c}0.013^{* * *} \\
(0.007)\end{array}$ & $\begin{array}{c}0.003 \\
(0.335)\end{array}$ & $\begin{array}{l}0.009^{*} \\
(0.053)\end{array}$ \\
\hline$M \& A(0,1)$ & & & $\begin{array}{c}0.030 * * * \\
(0.000)\end{array}$ & $\begin{array}{c}0.029 * * * \\
(0.000)\end{array}$ & & & $\begin{array}{c}0.028 * * * \\
(0.009)\end{array}$ & $\begin{array}{c}0.051^{* * *} \\
(0.005)\end{array}$ & & & $\begin{array}{c}0.030 * * * \\
(0.000)\end{array}$ & $\begin{array}{c}0.022^{* * *} \\
(0.001)\end{array}$ \\
\hline$H H I$ & & & 0.002 & 0.003 & & & 0.001 & 0.003 & & & 0.005 & 0.004 \\
\hline & & & $(0.406)$ & $(0.383)$ & & & $(0.787)$ & $(0.666)$ & & & $(0.141)$ & $(0.394)$ \\
\hline Local bank $(0,1)$ & & & $\begin{array}{l}-0.002 \\
(0.422)\end{array}$ & $\begin{array}{c}0.003 \\
(0.443)\end{array}$ & & & -0.001 & 0.002 & & & -0.003 & 0.002 \\
\hline
\end{tabular}




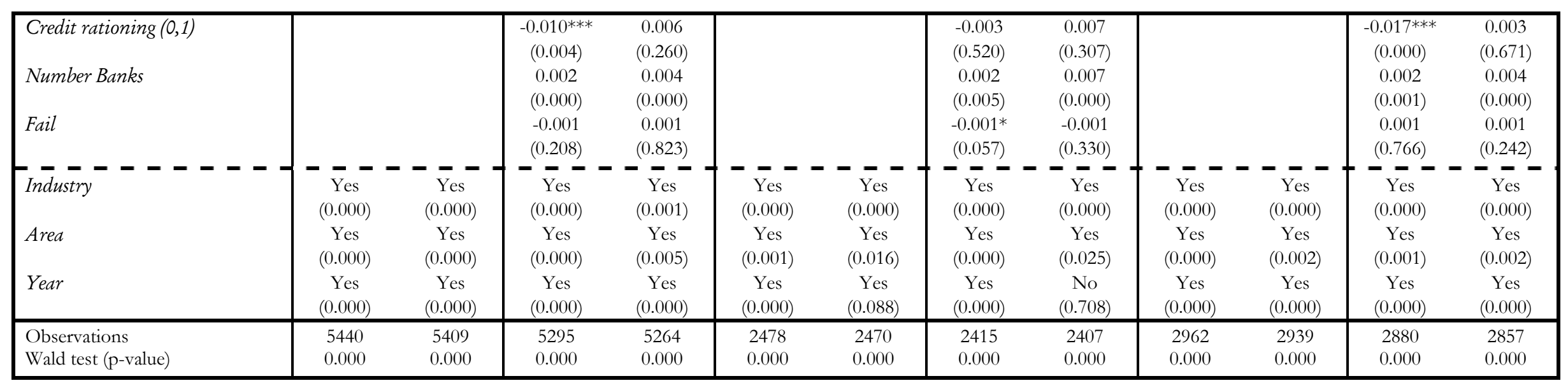


Table 4. Determinants of firms' growth. Instrumental variable results.

The table reports regression coefficients and associated p-values after instrumenting relationship lending. The dependent variable in columns (1), (2), (5), (6), (9) and (10) is the employment percentage rate of growth computed as the difference between the logarithms of the respective levels over the length of the period. The dependent variable in columns (3), (4), (7), (8), (11) and (12) is the assets percentage rate of growth computed as the difference between the logarithms of the respective levels over the length of the period. We measure relationship length with the main bank as the logarithm of 1 plus the number of years with the main bank minus 3 (divided by 10 ). Size is the logarithm of the number of employees at the beginning of the period. Age is the logarithm of the number of years since the inception of the firm. Cash flow is the ratio of cash flow to total assets. Leverage is the ratio of debt to total assets. The $(0,1)$ notation means the variable is a dummy taking the value of 1 if the firm presents the specified characteristic and 0 otherwise. To control for endogeneity of the length of the credit relationship Main-bank relationship length is instrumented by the control variables and five excluded instruments. Branches is the number of banks' branches in the province where the firm is headquartered, per 10000 inhabitants, in 1936. Cooperative banks and Saving banks are the shares of branches held by credit cooperative banks and saving banks respectively in the province where the firm is headquartered, in 1936. New branch entrant and Nere branch incumbent are, respectively, the average numbers of branches created by entrants and incumbents where the firm is headquartered in the province in 1991-1998 (divided by 1000). First-stage coefficients and pvalues for the excluded instruments are reported. In order to account for weakness of excluded instruments, coefficients in columns (1), (3), (5), (7), (9) and (11) are estimated by two-stage least squares (TSLS), while coefficients in columns (2), (4), (6), (8), (10) and (12) are estimated by limited-information maximum likelihood (LIML). Moreover, p-values from the standard $t$-test and the conditional likelihood ratio (CLR) test are reported for Main-bank relationship length. All regressions include industrial, geographic and time dummies. ${ }^{* *}$, ** and $*$ indicate statistically significant at the $1 \%, 5 \%$ and $10 \%$ level, respectively. The table also reports, as goodness-of-fit tests, the $F$-statistic for the $F$-test that the excluded instruments are jointly insignificant and the p-values of the $\chi^{2}$-statistics for the tests of endogeneity of regressors and for the Sargan overidentification test of all instruments and the p-value of the $F$-statistic of the Wald test of joint significance of regressors.

\begin{tabular}{|c|c|c|c|c|c|c|c|c|c|c|c|c|}
\hline & \multicolumn{4}{|c|}{ Panel A: whole sample } & \multicolumn{4}{|c|}{ Panel B: small business } & \multicolumn{4}{|c|}{ Panel C: medium-large business } \\
\hline & \multicolumn{2}{|c|}{ Employment } & \multicolumn{2}{|c|}{ Assets } & \multicolumn{2}{|c|}{ Employment } & \multicolumn{2}{|c|}{ Assets } & \multicolumn{2}{|c|}{ Employment } & \multicolumn{2}{|c|}{ Assets } \\
\hline & $\begin{array}{l}\text { TSLS } \\
(1)\end{array}$ & $\begin{array}{c}\text { LIML } \\
(2)\end{array}$ & $\begin{array}{c}\text { TSLS } \\
(3)\end{array}$ & $\begin{array}{c}\text { LIML } \\
(4)\end{array}$ & $\begin{array}{c}\text { TSLS } \\
(5)\end{array}$ & $\begin{array}{c}\text { LIML } \\
(6)\end{array}$ & $\begin{array}{c}\text { TSLS } \\
(7)\end{array}$ & $\begin{array}{c}\text { LIML } \\
(8)\end{array}$ & $\begin{array}{c}\text { TSLS } \\
(9)\end{array}$ & $\begin{array}{c}\text { LIML } \\
(10)\end{array}$ & $\begin{array}{c}\text { TSLS } \\
(11)\end{array}$ & $\begin{array}{c}\text { LIML } \\
(12)\end{array}$ \\
\hline Relationship-banking & & & & & & & & & & & & \\
\hline $\begin{array}{l}\text { Main-bank relationship length } \\
C L R \text { p-value }\end{array}$ & $\begin{array}{l}-0.002 \\
(0.994) \\
(0.976)\end{array}$ & $\begin{array}{c}0.004 \\
(0.993) \\
(0.976)\end{array}$ & $\begin{array}{c}0.578 \\
(0.239) \\
(0.132)\end{array}$ & $\begin{array}{c}1.206 \\
(0.148) \\
(0.132)\end{array}$ & $\begin{array}{c}-1.241 * * \\
(0.040) \\
(0.012)\end{array}$ & $\begin{array}{c}-1.325^{* *} \\
(0.040) \\
(0.012)\end{array}$ & $\begin{array}{l}-1.078 \\
(0.184) \\
(0.175)\end{array}$ & $\begin{array}{l}-1.923 \\
(0.161) \\
(0.175)\end{array}$ & $\begin{array}{c}0.473 \\
(0.196) \\
(0.171)\end{array}$ & $\begin{array}{c}0.793 \\
(0.151) \\
(0.171)\end{array}$ & $\begin{array}{c}1.227 *(*) \\
(0.059) \\
(0.038)\end{array}$ & $\begin{array}{c}1.361 *(*) \\
(0.057) \\
(0.038)\end{array}$ \\
\hline$\underline{\text { Controls }}$ & & & & & & & & & & & & \\
\hline $\begin{array}{l}\text { Size } \\
\text { Age }\end{array}$ & $\begin{array}{c}-0.009 * * * \\
(0.000) \\
-0.008 \\
(0.689)\end{array}$ & $\begin{array}{c}-0.009 * * * \\
(0.000) \\
-0.009 \\
(0.778)\end{array}$ & $\begin{array}{c}-0.009 * * * \\
(0.000) \\
-0.053 \\
(0.125)\end{array}$ & $\begin{array}{c}-0.007 * \\
(0.073) \\
-0.097 * \\
(0.098)\end{array}$ & $\begin{array}{c}-0.035^{* * *} \\
(0.000) \\
0.083^{*} \\
(0.071)\end{array}$ & $\begin{array}{c}-0.035^{* * *} \\
(0.000) \\
0.089^{*} \\
(0.069)\end{array}$ & $\begin{array}{c}-0.033^{* * *} \\
(0.000) \\
0.057 \\
(0.360)\end{array}$ & $\begin{array}{c}-0.036 * * * \\
(0.000) \\
0.121 \\
(0.247)\end{array}$ & $\begin{array}{c}-0.012 * * * \\
(0.000) \\
-0.038 \\
(0.115)\end{array}$ & $\begin{array}{c}-0.011 * * * \\
(0.000) \\
-0.059 \\
(0.105)\end{array}$ & $\begin{array}{c}-0.012^{* * *} \\
(0.010) \\
-0.085^{* *} \\
(0.047)\end{array}$ & $\begin{array}{c}-0.012^{* *} \\
(0.024) \\
-0.094^{* *} \\
(0.046)\end{array}$ \\
\hline Cash flow & $\begin{array}{c}0.237^{* * *} \\
(0.000)\end{array}$ & $\begin{array}{c}0.237 * * * \\
(0.000)\end{array}$ & $\begin{array}{c}0.284 * * * \\
(0.000)\end{array}$ & $\begin{array}{c}0.286^{* * *} \\
(0.000)\end{array}$ & $\begin{array}{c}0.181 * * * \\
(0.000)\end{array}$ & $\begin{array}{c}0.180^{* * *} \\
(0.000)\end{array}$ & $\begin{array}{c}0.183^{* * *} \\
(0.002)\end{array}$ & $\begin{array}{c}0.177 * * \\
(0.019)\end{array}$ & $\begin{array}{c}0.287 * * * \\
(0.000)\end{array}$ & $\begin{array}{c}0.285^{* * * *} \\
(0.000)\end{array}$ & $\begin{array}{c}0.358^{* * *} \\
(0.000)\end{array}$ & $\begin{array}{c}0.358^{* * *} \\
(0.000)\end{array}$ \\
\hline Leverage & $\begin{array}{c}0.052^{* * *} \\
(0.000)\end{array}$ & $\begin{array}{c}0.052^{* * *} \\
(0.003)\end{array}$ & $\begin{array}{c}0.049 * * \\
(0.023)\end{array}$ & $\begin{array}{c}0.072^{* *} \\
(0.032)\end{array}$ & $\begin{array}{c}0.009 \\
(0.738)\end{array}$ & $\begin{array}{c}0.006 \\
(0.835)\end{array}$ & $\begin{array}{l}-0.017 \\
(0.626)\end{array}$ & $\begin{array}{l}-0.047 \\
(0.388)\end{array}$ & $\begin{array}{c}0.063 * * * \\
(0.000)\end{array}$ & $\begin{array}{c}0.075 * * * \\
(0.002)\end{array}$ & $\begin{array}{c}0.079 * * \\
(0.014)\end{array}$ & $\begin{array}{c}0.084^{* *} \\
(0.015)\end{array}$ \\
\hline Export $(0,1)$ & $\begin{array}{c}0.009^{* * *} \\
(0.003)\end{array}$ & $\begin{array}{c}0.009^{* * *} \\
(0.007)\end{array}$ & $\begin{array}{c}0.018^{* * *} \\
(0.001)\end{array}$ & $\begin{array}{c}0.015^{* *} \\
(0.026)\end{array}$ & $\begin{array}{c}0.006 \\
(0.291)\end{array}$ & $\begin{array}{c}0.005 \\
(0.315)\end{array}$ & $\begin{array}{c}0.020^{* * *} \\
(0.004)\end{array}$ & $\begin{array}{c}0.020^{* *} \\
(0.021)\end{array}$ & $\begin{array}{c}0.003 \\
(0.636)\end{array}$ & $\begin{array}{l}-0.001 \\
(0.965)\end{array}$ & $\begin{array}{c}0.004 \\
(0.690)\end{array}$ & $\begin{array}{c}0.003 \\
(0.798)\end{array}$ \\
\hline $\operatorname{Group}(0,1)$ & $\begin{array}{l}0.011^{*} \\
(0.067) \\
\end{array}$ & $\begin{array}{c}0.011 \\
(0.189) \\
\end{array}$ & $\begin{array}{c}0.014 \\
(0.181) \\
\end{array}$ & $\begin{array}{c}0.025 \\
(0.123) \\
\end{array}$ & $\begin{array}{l}-0.006 \\
(0.595) \\
\end{array}$ & $\begin{array}{l}-0.007 \\
(0.547) \\
\end{array}$ & $\begin{array}{r}-0.004 \\
(0.791) \\
\end{array}$ & $\begin{array}{l}-0.015 \\
(0.493) \\
\end{array}$ & $\begin{array}{c}0.019 * * \\
(0.032) \\
\end{array}$ & $\begin{array}{c}0.026^{* *} \\
(0.044) \\
\end{array}$ & $\begin{array}{l}0.027^{*} \\
(0.071) \\
\end{array}$ & $\begin{array}{l}0.029^{*} \\
(0.067) \\
\end{array}$ \\
\hline
\end{tabular}




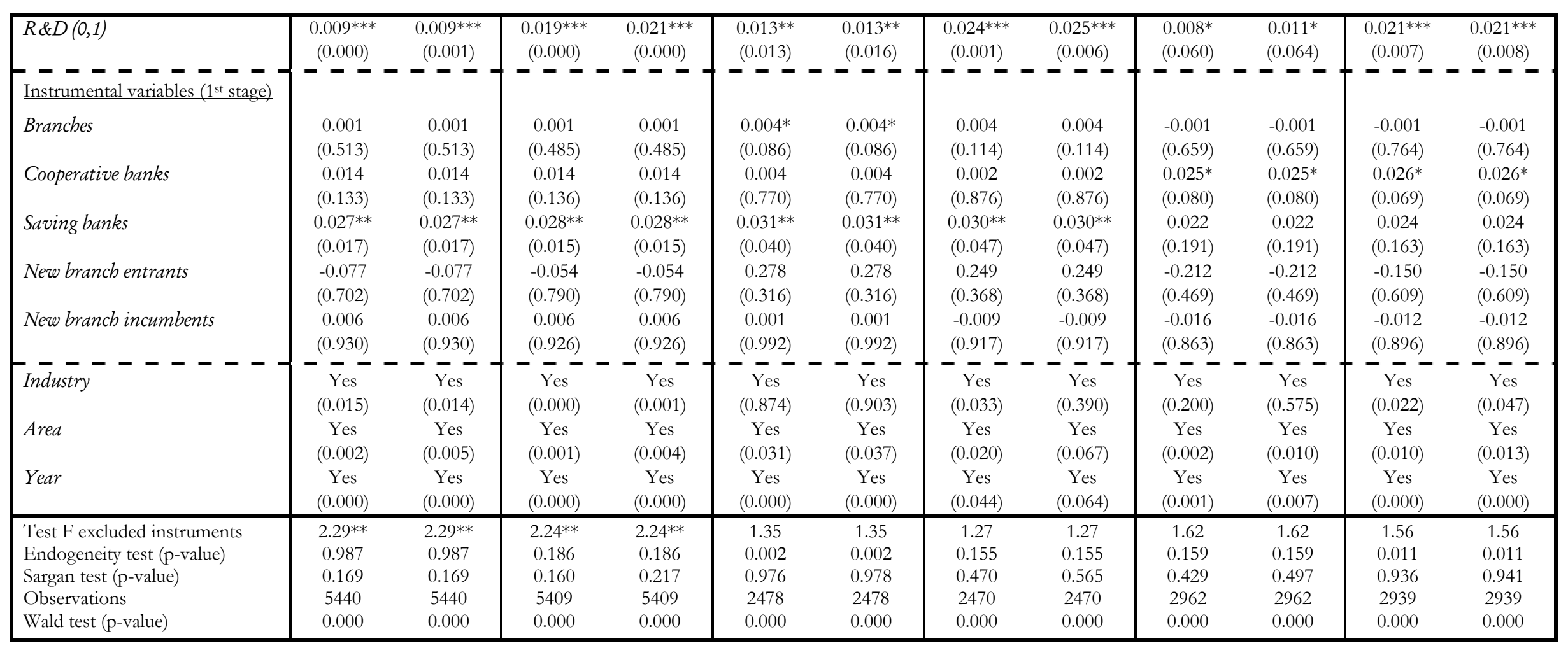


Table 5. Weak-instrument-robust inference on Main-bank relationship length.

The table reports the 95 percent confidence intervals and the p-values from the test on the coefficient of Main-bank relationship length based on the conditional likelihood ratio (CLR), the Anderson-Rubin and the Lagrange multiplier (score) test statistics. The CLR test developed by Moreira (2003) dominates the Anderson Rubin and the Lagrange multiplier (score) tests and its $\mathrm{p}$-value is also reported in Table 4 together with the p-value from the standard $t$-test.

\begin{tabular}{|l|c|c|c|c|c|c|}
\hline & \multicolumn{2}{|c|}{ Panel A: whole sample } & Panel B: small business & \multicolumn{3}{c|}{$\begin{array}{c}\text { Panel C: medium-large } \\
\text { business }\end{array}$} \\
& Employment & Assets & Employment & Assets & Employment & Assets \\
\hline Conditional LR & {$[-\infty,+\infty]$} & {$[-\infty,+\infty]$} & {$[-22.011,-0.329]$} & {$[-\infty,+\infty]$} & {$[-\infty,+\infty]$} & {$[0.095,23.207]$} \\
CLR p-value & $(0.976)$ & $(0.132)$ & $(0.012) * *$ & $(0.175)$ & $(0.171)$ & $(0.038) * *$ \\
\hline Anderson-Rubin & {$[-3.355,3.638]$} & {$[-0.334,91.374]$} & {$[-\infty,+\infty]$} & {$[-\infty,+\infty]$} & {$[-\infty,+\infty]$} & {$[-\infty,+\infty]$} \\
AR p-value & $(0.271)$ & $(0.104)$ & $(0.049) * *$ & $(0.228)$ & $(0.238)$ & $(0.159)$ \\
\hline Score (LM) & {$[-\infty,+\infty]$} & {$[-\infty,+\infty]$} & {$[-6.559,0.933]$} & {$[-\infty,+\infty]$} & {$[-\infty,+\infty]$} & {$[-1.785,6.330]$} \\
\hline LMp-value & $(0.995)$ & $(0.193)$ & $(0.002) * * *$ & $(0.150)$ & $(0.156)$ & $(0.011) * *$ \\
\hline
\end{tabular}


Table 6. The occupational-changing choice. Multinomial logit results.

The table reports multinomial-logit-regression relative risk ratios of standardized independent variables and associated pvalues. The categorical dependent variable takes the value of 1, 2 and 3, accounting respectively for positive, zero and negative employment growth. The base outcome is 2 corresponding to zero growth. Columns (1) and (3) report relative risk ratios and associated p-values of positive growth versus zero growth for small and medium-large business respectively, while columns (2) and (4) report relative risk ratios and associated p-values of negative growth versus zero growth for small and medium-large business respectively. Independent variables are standardized before running the regressions. Being in the same standardized units the relative risk ratios can be compared to assess the relative strength of each of the predictors. We measure relationship length with the main bank as the logarithm of 1 plus the number of years with the main bank minus 3 (divided by 10). Size is the logarithm of the number of employees at the beginning of the period. Age is the logarithm of the number of years since the inception of the firm. Cash flow is the ratio of cash flow to total assets. Leverage is the ratio of debt to total assets. The $(0,1)$ notation means the variable is a dummy taking the value of 1 if the firm presents the specified characteristic and 0 otherwise. All regressions include industrial, geographic and time dummies. ***, ** and * indicate statistically significance at the $1 \%, 5 \%$ and $10 \%$ level, respectively. The table also reports, as a goodness-of-fit test, the pvalues of the $\chi^{2}$-statistic for the Hausman test of independence of irrelevant alternatives and of the $F$-statistic for the LR test of joint significance of regressors. At the bottom of the table we report the theoretical probability of positive, zero and negative growth for the average firm when the explanatory variable Main-bank relationship length is at its $25^{\text {th }}$ and $75^{\text {th }}$ percentiles.

\begin{tabular}{|c|c|c|c|c|}
\hline & \multicolumn{2}{|c|}{ Panel A: small business } & \multicolumn{2}{|c|}{ Panel B: medium-large business } \\
\hline & $\begin{array}{l}\text { Positive vs } \\
\text { zero growth } \\
\text { (1) }\end{array}$ & $\begin{array}{l}\text { Negative vs } \\
\text { zero growth } \\
\text { (2) }\end{array}$ & $\begin{array}{l}\text { Positive vs } \\
\text { zero growth } \\
\text { (3) }\end{array}$ & $\begin{array}{l}\text { Negative vs } \\
\text { zero growth } \\
\text { (4) }\end{array}$ \\
\hline $\begin{array}{l}\text { Relationship-banking } \\
\text { Main-bank relationship }\end{array}$ & $\begin{array}{c}0.875^{* *} \\
(0.028)\end{array}$ & $\begin{array}{l}0.962 \\
(0.575)\end{array}$ & $\begin{array}{c}0.949 \\
(0.325)\end{array}$ & $\begin{array}{c}0.857 * * * \\
(0.008)\end{array}$ \\
\hline \multicolumn{5}{|l|}{$\underline{\text { Controls }}$} \\
\hline Size & $\begin{array}{c}1.795^{* * *} \\
(0.000)\end{array}$ & $\begin{array}{c}3.807 * * * \\
(0.000)\end{array}$ & $\begin{array}{c}1.415^{* * *} \\
(0.000)\end{array}$ & $\begin{array}{c}2.102^{* * *} \\
(0.000)\end{array}$ \\
\hline Age & $\begin{array}{c}0.933 \\
(0.290)\end{array}$ & $\begin{array}{c}1.107 \\
(0.187)\end{array}$ & $\begin{array}{c}1.028 \\
(0.641)\end{array}$ & $\begin{array}{c}1.202^{* * *} \\
(0.005)\end{array}$ \\
\hline Cash flow & $\begin{array}{c}1.192 * * * \\
(0.001)\end{array}$ & $\begin{array}{c}0.786^{* * *} \\
(0.000)\end{array}$ & $\begin{array}{c}1.294^{* * *} \\
(0.000)\end{array}$ & $\begin{array}{c}0.767^{* * *} * \\
(0.000)\end{array}$ \\
\hline Leverage & $\begin{array}{c}1.285^{* * *} \\
(0.000)\end{array}$ & $\begin{array}{l}0.937 \\
(0.291\end{array}$ & $\begin{array}{c}1.216^{* * *} \\
(0.001)\end{array}$ & $\begin{array}{c}0.939 \\
(0.321)\end{array}$ \\
\hline Export $(0,1)$ & $\begin{array}{c}1.048 \\
(0.322)\end{array}$ & $\begin{array}{c}0.944 \\
(0.295)\end{array}$ & $\begin{array}{l}1.127^{* *} \\
(0.039)\end{array}$ & $\begin{array}{c}0.988 \\
(0.860)\end{array}$ \\
\hline $\operatorname{Group}(0,1)$ & $\begin{array}{c}1.084 \\
(0.218)\end{array}$ & $\begin{array}{c}0.892 \\
(0.183)\end{array}$ & $\begin{array}{c}1.056 \\
(0.246)\end{array}$ & $\begin{array}{c}0.985 \\
(0.779)\end{array}$ \\
\hline$R \& D(0,1)$ & $\begin{array}{c}1.185^{* * *} \\
(0.001)\end{array}$ & $\begin{array}{c}1.013 \\
(0.841)\end{array}$ & $\begin{array}{c}1.038 \\
(0.464)\end{array}$ & $\begin{array}{c}1.050 \\
(0.398)\end{array}$ \\
\hline $\begin{array}{l}\text { Industry } \\
\text { Area } \\
\text { Year }\end{array}$ & $\begin{array}{l}\text { Yes } \\
\text { Yes } \\
\text { Yes }\end{array}$ & $\begin{array}{l}\text { Yes } \\
\text { Yes } \\
\text { Yes }\end{array}$ & $\begin{array}{l}\text { Yes } \\
\text { Yes } \\
\text { Yes }\end{array}$ & $\begin{array}{l}\text { Yes } \\
\text { Yes } \\
\text { Yes }\end{array}$ \\
\hline $\begin{array}{l}\text { Hausman test } \\
\text { Observations } \\
\text { LR test (p-value) }\end{array}$ & $\begin{array}{l}0.856 \\
2478 \\
0.000\end{array}$ & $\begin{array}{l}0.368 \\
2478 \\
0.000\end{array}$ & $\begin{array}{l}0.503 \\
2962 \\
0.000\end{array}$ & $\begin{array}{l}0.495 \\
2962 \\
0.000\end{array}$ \\
\hline \multicolumn{5}{|c|}{ The effects of Main-bank relationship-length on the probability of the average firm growing } \\
\hline & $\begin{array}{r}\mathrm{Sm} \\
\text { 25th percentile } \\
\end{array}$ & $\begin{array}{l}\text { less } \\
75 \text { th percentile }\end{array}$ & $\begin{array}{l}\text { Mediun } \\
\text { 25th percentile }\end{array}$ & $\begin{array}{l}\text { usiness } \\
75 \text { th percentile }\end{array}$ \\
\hline $\begin{array}{l}\text { Probability of positive growth } \\
\text { Probability of zero growth } \\
\text { Probability of negative growth }\end{array}$ & $\begin{array}{l}0.350 \\
0.444 \\
0.206\end{array}$ & $\begin{array}{l}0.323 \\
0.469 \\
0.209\end{array}$ & $\begin{array}{l}0.491 \\
0.235 \\
0.273\end{array}$ & $\begin{array}{l}0.500 \\
0.256 \\
0.244\end{array}$ \\
\hline
\end{tabular}


Table 7. The occupational-intensity choice. Heckit results.

The table reports Heckman two-step procedure results for the two selection models on occupational intensity choice. Columns (1), (3), (5) and (7) report coefficients and associated p-values of the first-stage probit regressions on the selection equations. The dependent variable in columns (1) and (5) ((3) and (7)) is the probability of firms increasing (decreasing) occupation. Three additional variables are included in the selection equations: Roa, a dummy variable taking the value of 1 for firms with a return on assets ratio greater than 0 and 0 otherwise, Default risk, a dummy variable taking if the value of 1 for firms whose one-year probability of default is greater than 0.053 (the median value for the whole sample) and Credit rationing, a dummy variable taking the value of 1 if the firm reports it have desired more credit at the interest rate agreed with the bank and 0 otherwise. The dependent variable in columns (2), (4), (6) and (8) is the employment percentage rate of growth computed as the difference between the logarithms of the respective levels over the length of the period. We measure relationship length with the main bank as the logarithm of 1 plus the number of years with the main bank minus 3 (divided by 10). Size is the logarithm of number of employees at the beginning of the period. Age is the logarithm of the number of years since the inception of the firm. Cash flow is the ratio of cash flow to total assets. Leverage is the ratio of debt to total assets. The $(0,1)$ notation means the variable is a dummy taking the value of 1 if the firm presents the specified characteristic and 0 otherwise. All regressions include industrial, geographic and time dummies. $* * *$, $* *$ and $*$ indicate statistically significant at the $1 \%, 5 \%$ and $10 \%$ level, respectively. The table also reports, as goodness-of-fit test, the p-values of the $F$-statistic for the Wald test of joint significance of regressors.

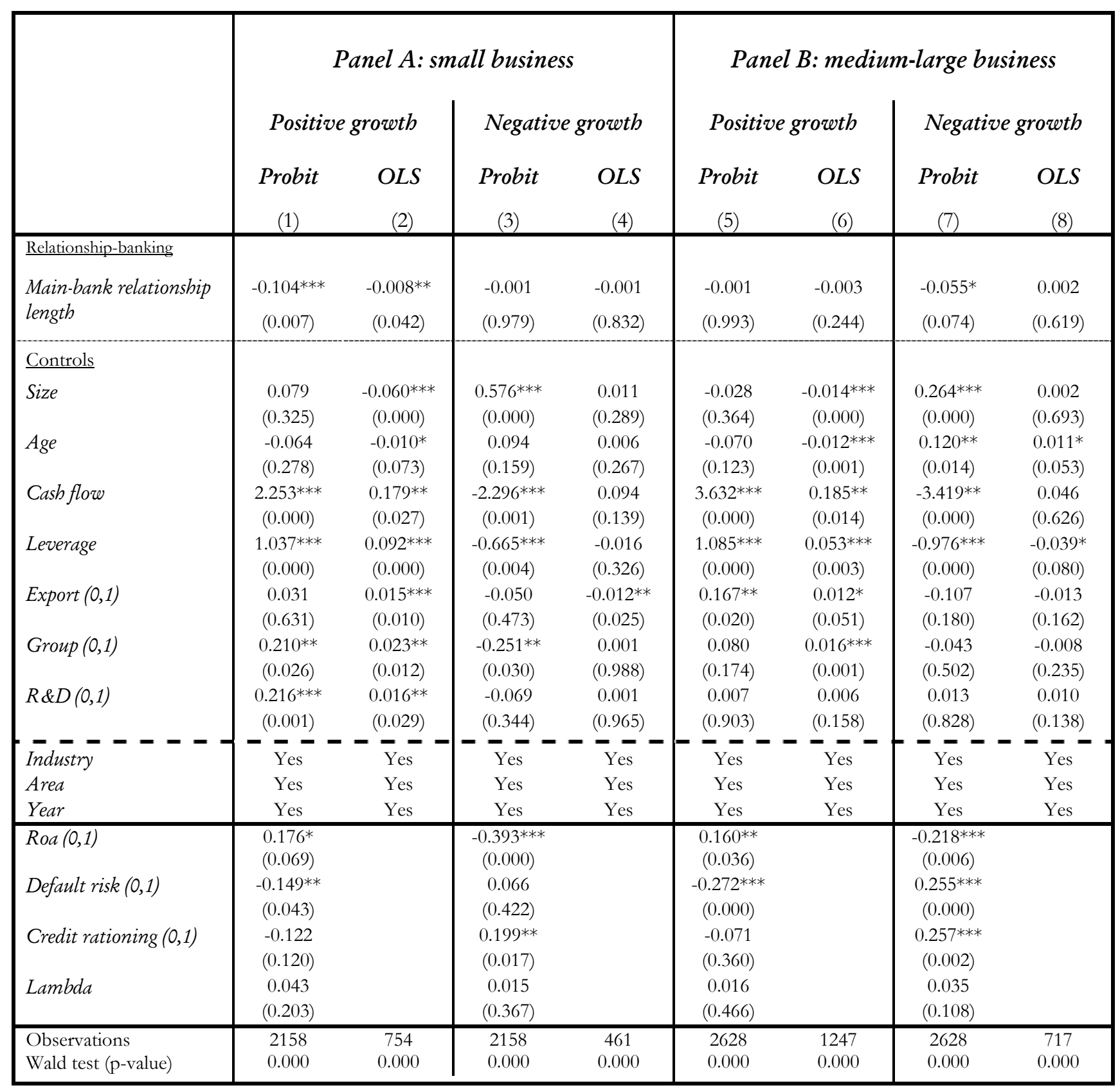



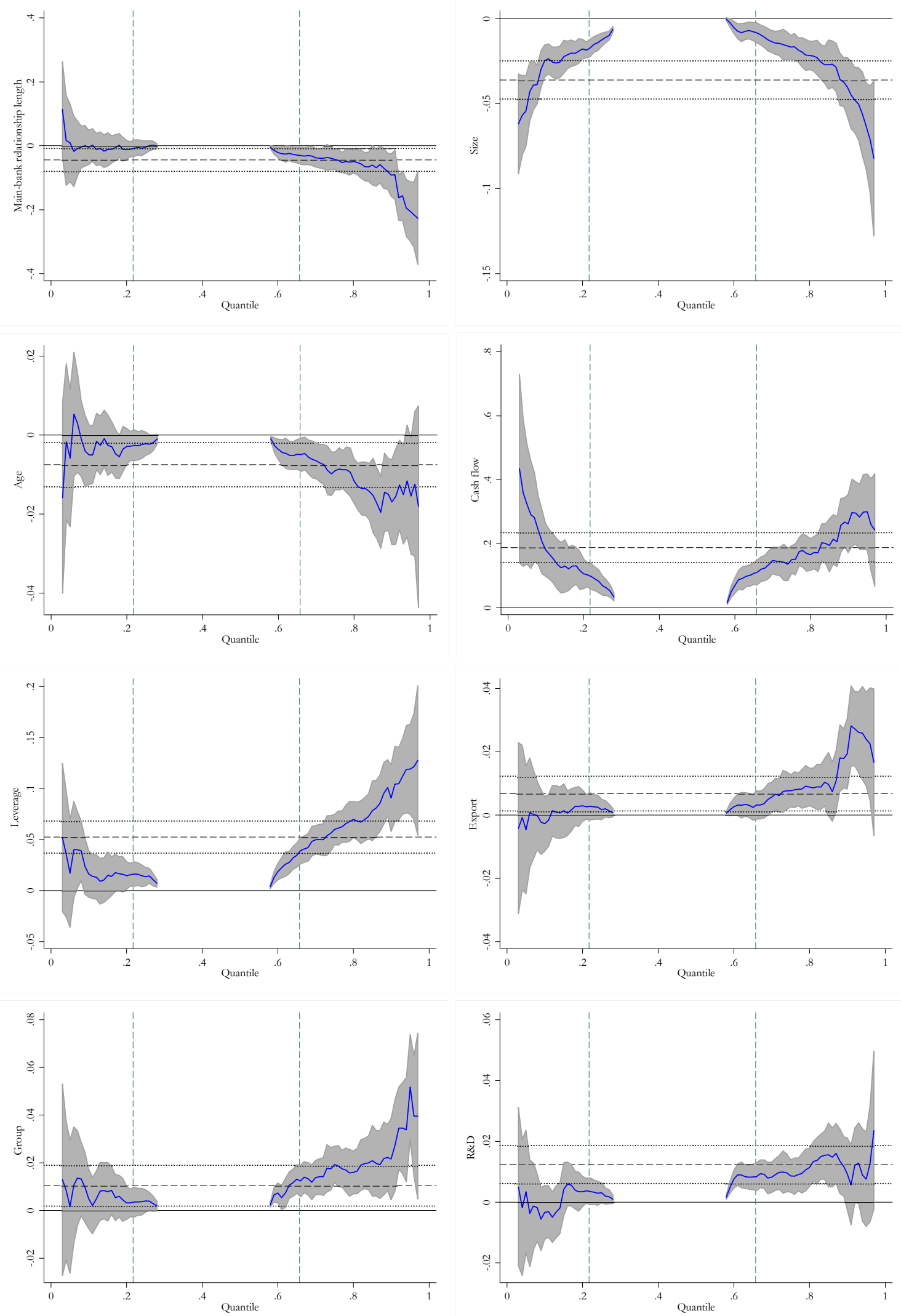

Figure 1A. Small business employment growth. Quantile regression results. 

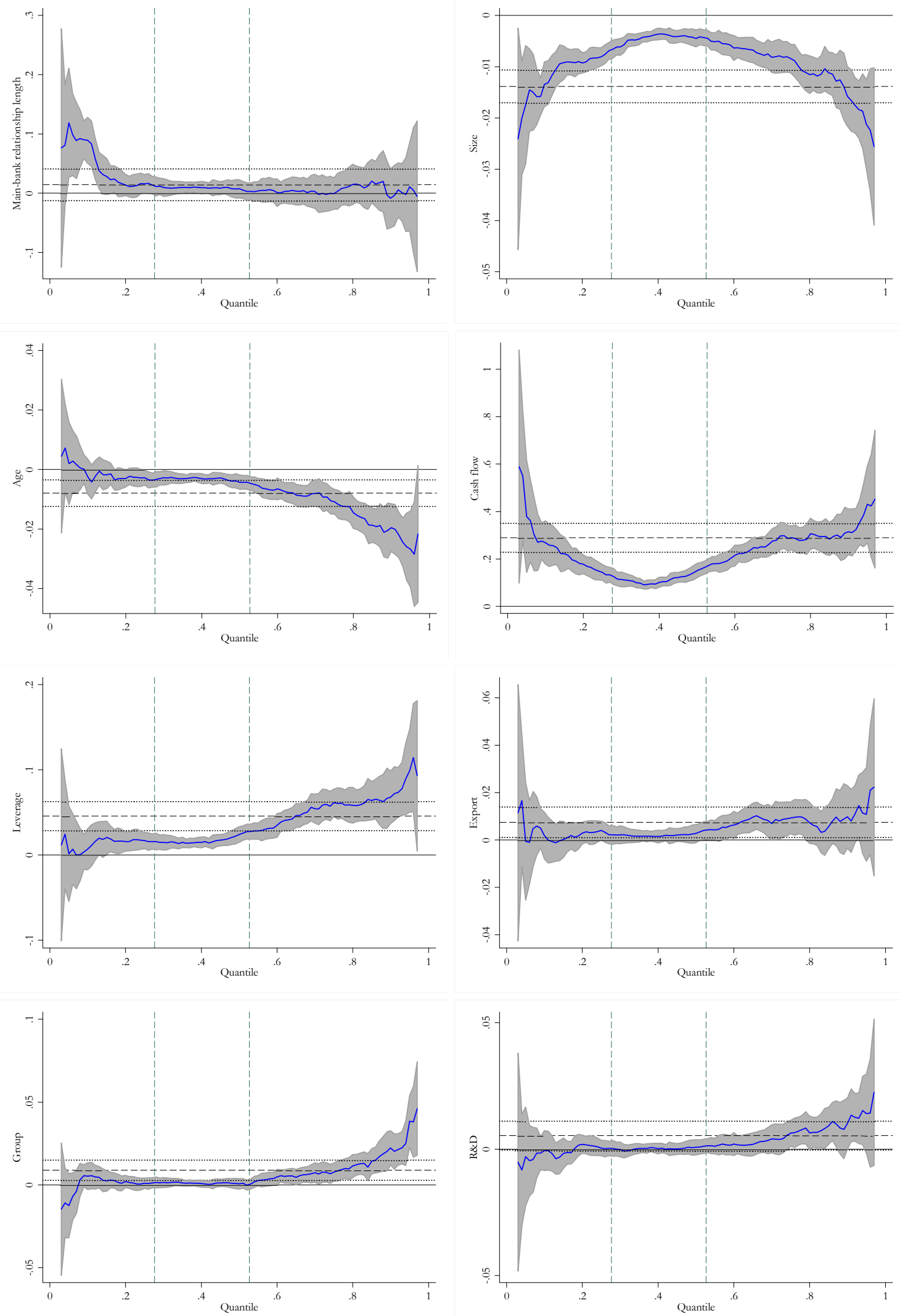

Figure 1B. Medium-large business employment growth. Quantile regression results. 

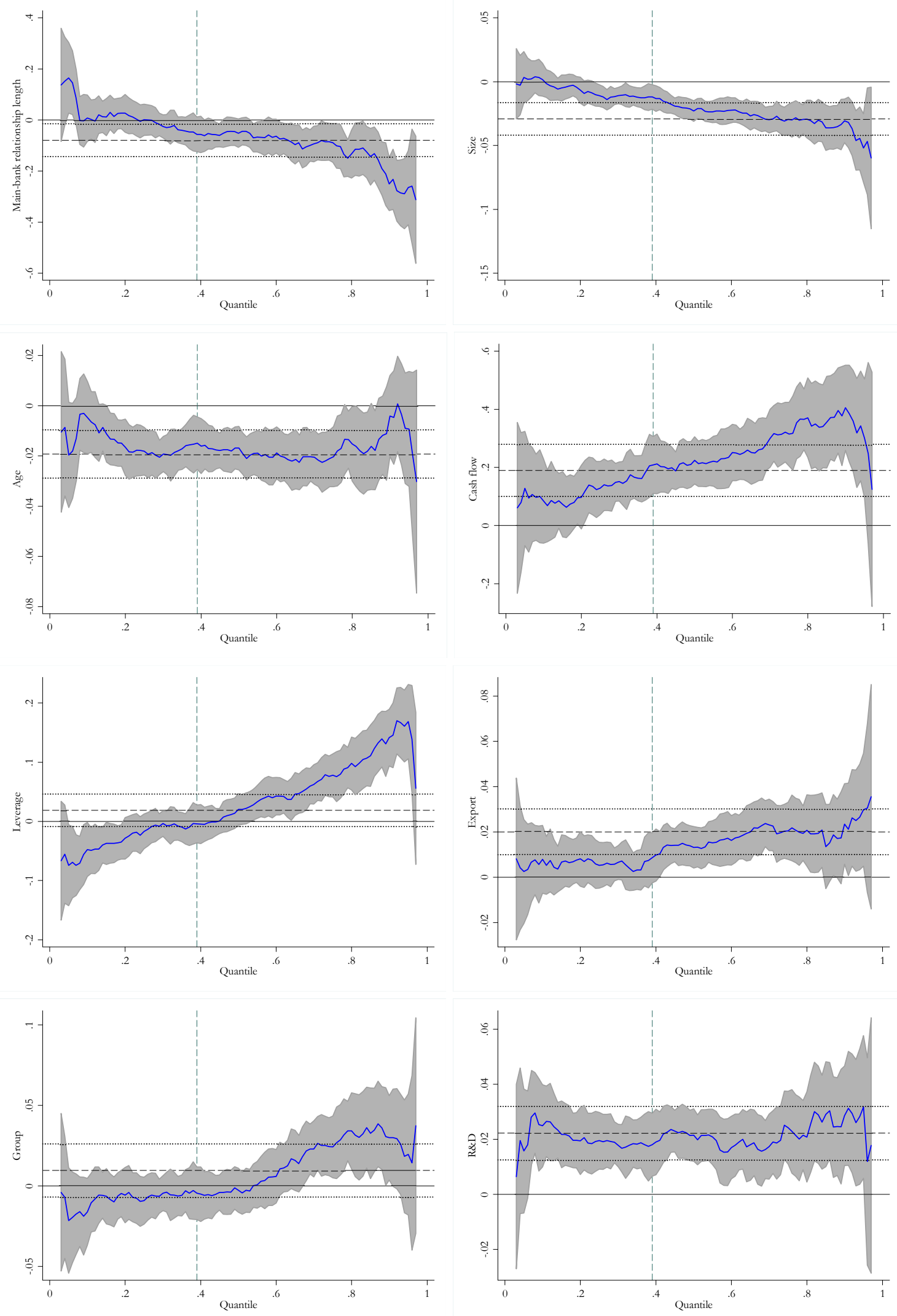

Figure 1C. Small business assets growth. Quantile regression results. 

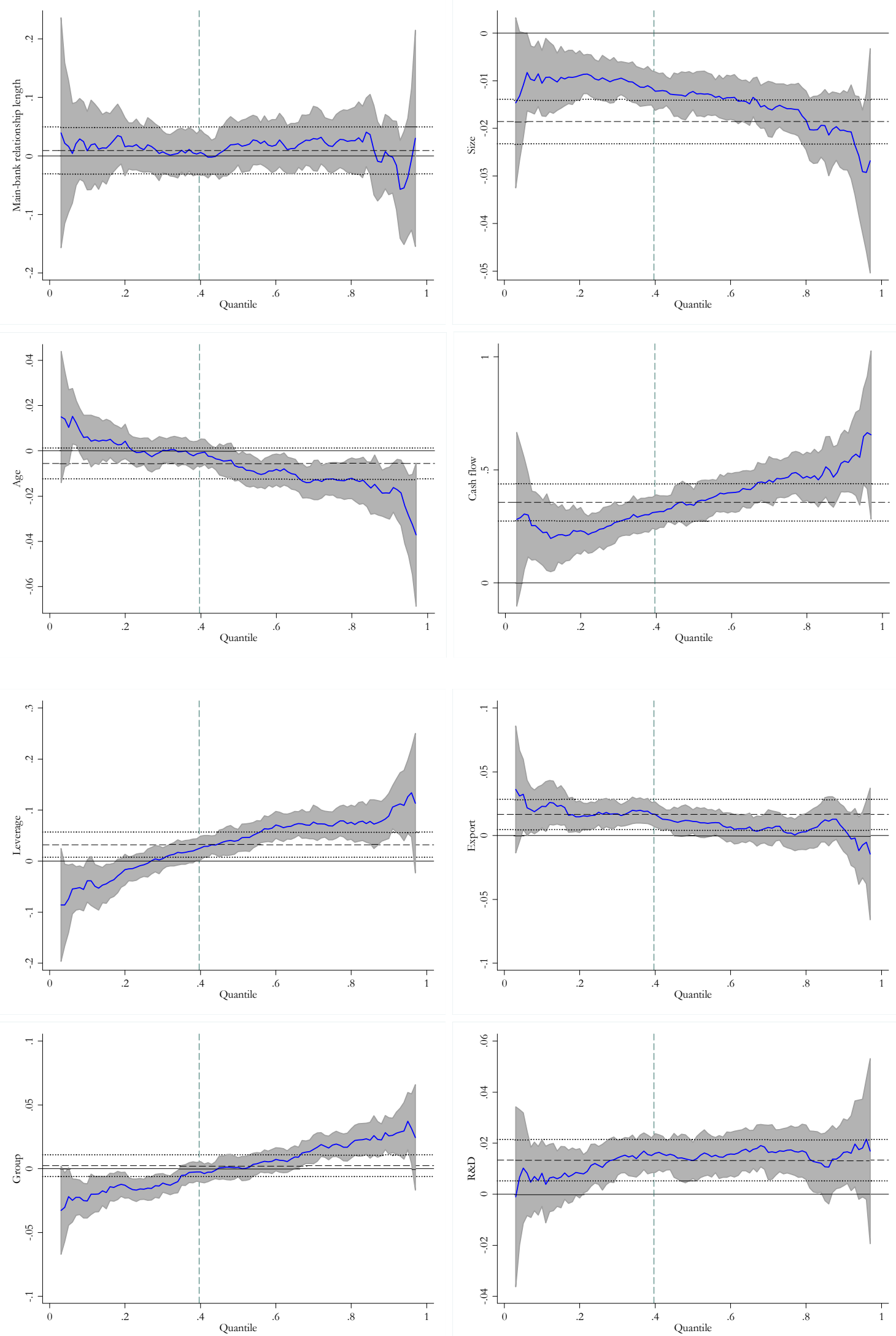

Figure 1D. Medium-large business assets growth. Quantile regression results. 


\section{CESifo Working Paper Series}

for full list see www.cesifo-group.org/wp

(address: Poschingerstr. 5, 81679 Munich, Germany, office@cesifo.de)

3041 Matthias Wrede, Multinational Capital Structure and Tax Competition, April 2010

3042 Burkhard Heer and Alfred Maussner, A Note on the Computation of the Equity Premium and the Market Value of Firm Equity, April 2010

3043 Kristiina Huttunen, Jukka Pirttilä and Roope Uusitalo, The Employment Effects of Low-Wage Subsidies, May 2010

3044 Matthias Kalkuhl and Ottmar Edenhofer, Prices vs. Quantities and the Intertemporal Dynamics of the Climate Rent, May 2010

3045 Bruno S. Frey and Lasse Steiner, Pay as you Go: A New Proposal for Museum Pricing, May 2010

3046 Henning Bohn and Charles Stuart, Population under a Cap on Greenhouse Gas Emissions, May 2010

3047 Balázs Égert and Rafal Kierzenkowski, Exports and Property Prices in France: Are they Connected?, May 2010

3048 Thomas Eichner and Thorsten Upmann, Tax-Competition with Involuntary Unemployment, May 2010

3049 Taiji Furusawa, Kazumi Hori and Ian Wooton, A Race beyond the Bottom: The Nature of Bidding for a Firm, May 2010

3050 Xavier Vives, Competition and Stability in Banking, May 2010

3051 Thomas Aronsson and Erkki Koskela, Redistributive Income Taxation under Outsourcing and Foreign Direct Investment, May 2010

3052 Michael Melvin and Duncan Shand, Active Currency Investing and Performance Benchmarks, May 2010

3053 Sören Blomquist and Laurent Simula, Marginal Deadweight Loss when the Income Tax is Nonlinear, May 2010

3054 Lukas Menkhoff, Carol L. Osler and Maik Schmeling, Limit-Order Submission Strategies under Asymmetric Information, May 2010

3055 M. Hashem Pesaran and Alexander Chudik, Econometric Analysis of High Dimensional VARs Featuring a Dominant Unit, May 2010

3056 Rabah Arezki and Frederick van der Ploeg, Do Natural Resources Depress Income Per Capita?, May 2010 
3057 Joseph Plasmans and Ruslan Lukach, The Patterns of Inter-firm and Inter-industry Knowledge Flows in the Netherlands, May 2010

3058 Jenny E. Ligthart and Sebastian E. V. Werner, Has the Euro Affected the Choice of Invoicing Currency?, May 2010

3059 Håkan Selin, Marginal Tax Rates and Tax-Favoured Pension Savings of the SelfEmployed - Evidence from Sweden, May 2010

3060 Richard Cornes, Roger Hartley and Yuji Tamura, A New Approach to Solving Production-Appropriation Games with Many Heterogeneous Players, May 2010

3061 Ronald MacDonald and Flávio Vieira, A Panel Data Investigation of Real Exchange Rate Misalignment and Growth, May 2010

3062 Thomas Eichner and Rüdiger Pethig, Efficient Management of Insecure Fossil Fuel Imports through Taxing(!) Domestic Green Energy?, May 2010

3063 Vít Bubák, Evžen Kočenda and Filip Žikeš, Volatility Transmission in Emerging European Foreign Exchange Markets, May 2010

3064 Leonid V. Azarnert, Après nous le Déluge: Fertility and the Intensity of Struggle against Immigration, May 2010

3065 William E. Becker, William H. Greene and John J. Siegfried, Do Undergraduate Majors or Ph.D. Students Affect Faculty Size?, May 2010

3066 Johannes Becker, Strategic Trade Policy through the Tax System, May 2010

3067 Omer Biran and Françoise Forges, Core-stable Rings in Auctions with Independent Private Values, May 2010

3068 Torben M. Andersen, Why do Scandinavians Work?, May 2010

3069 Andrey Launov and Klaus Wälde, Estimating Incentive and Welfare Effects of NonStationary Unemployment Benefits, May 2010

3070 Simon Gächter, Benedikt Herrmann and Christian Thöni, Culture and Cooperation, June 2010

3071 Mehmet Bac and Eren Inci, The Old-Boy Network and the Quality of Entrepreneurs, June 2010

3072 Krisztina Molnár and Sergio Santoro, Optimal Monetary Policy when Agents are Learning, June 2010

3073 Marcel Boyer and Donatella Porrini, Optimal Liability Sharing and Court Errors: An Exploratory Analysis, June 2010 
3074 Guglielmo Maria Caporale, Roman Matousek and Chris Stewart, EU Banks Rating Assignments: Is there Heterogeneity between New and Old Member Countries? June 2010

3075 Assaf Razin and Efraim Sadka, Fiscal and Migration Competition, June 2010

3076 Shafik Hebous, Martin Ruf and Alfons Weichenrieder, The Effects of Taxation on the Location Decision of Multinational Firms: M\&A vs. Greenfield Investments, June 2010

3077 Alessandro Cigno, How to Deal with Covert Child Labour, and Give Children an Effective Education, in a Poor Developing Country: An Optimal Taxation Problem with Moral Hazard, June 2010

3078 Bruno S. Frey and Lasse Steiner, World Heritage List: Does it Make Sense?, June 2010

3079 Henning Bohn, The Economic Consequences of Rising U.S. Government Debt: Privileges at Risk, June 2010

3080 Rebeca Jiménez-Rodriguez, Amalia Morales-Zumaquero and Balázs Égert, The VARying Effect of Foreign Shocks in Central and Eastern Europe, June 2010

3081 Stephane Dees, M. Hashem Pesaran, L. Vanessa Smith and Ron P. Smith, Supply, Demand and Monetary Policy Shocks in a Multi-Country New Keynesian Model, June 2010

3082 Sara Amoroso, Peter Kort, Bertrand Melenberg, Joseph Plasmans and Mark Vancauteren, Firm Level Productivity under Imperfect Competition in Output and Labor Markets, June 2010

3083 Thomas Eichner and Rüdiger Pethig, International Carbon Emissions Trading and Strategic Incentives to Subsidize Green Energy, June 2010

3084 Henri Fraisse, Labour Disputes and the Game of Legal Representation, June 2010

3085 Andrzej Baniak and Peter Grajzl, Interjurisdictional Linkages and the Scope for Interventionist Legal Harmonization, June 2010

3086 Oliver Falck and Ludger Woessmann, School Competition and Students' Entrepreneurial Intentions: International Evidence Using Historical Catholic Roots of Private Schooling, June 2010

3087 Bernd Hayo and Stefan Voigt, Determinants of Constitutional Change: Why do Countries Change their Form of Government?, June 2010

3088 Momi Dahan and Michel Strawczynski, Fiscal Rules and Composition Bias in OECD Countries, June 2010

3089 Marcel Fratzscher and Julien Reynaud, IMF Surveillance and Financial Markets - A Political Economy Analysis, June 2010 
3090 Michel Beine, Elisabetta Lodigiani and Robert Vermeulen, Remittances and Financial Openness, June 2010

3091 Sebastian Kube and Christian Traxler, The Interaction of Legal and Social Norm Enforcement, June 2010

3092 Volker Grossmann, Thomas M. Steger and Timo Trimborn, Quantifying Optimal Growth Policy, June 2010

3093 Huw David Dixon, A Unified Framework for Using Micro-Data to Compare Dynamic Wage and Price Setting Models, June 2010

3094 Helmuth Cremer, Firouz Gahvari and Pierre Pestieau, Accidental Bequests: A Curse for the Rich and a Boon for the Poor, June 2010

3095 Frank Lichtenberg, The Contribution of Pharmaceutical Innovation to Longevity Growth in Germany and France, June 2010

3096 Simon P. Anderson, Øystein Foros and Hans Jarle Kind, Hotelling Competition with Multi-Purchasing: Time Magazine, Newsweek, or both?, June 2010

3097 Assar Lindbeck and Mats Persson, A Continuous Theory of Income Insurance, June 2010

3098 Thomas Moutos and Christos Tsitsikas, Whither Public Interest: The Case of Greece's Public Finance, June 2010

3099 Thomas Eichner and Thorsten Upmann, Labor Markets and Capital Tax Competition, June 2010

3100 Massimo Bordignon and Santino Piazza, Who do you Blame in Local Finance? An Analysis of Municipal Financing in Italy, June 2010

3101 Kyriakos C. Neanidis, Financial Dollarization and European Union Membership, June 2010

3102 Maela Giofré, Investor Protection and Foreign Stakeholders, June 2010

3103 Andrea F. Presbitero and Alberto Zazzaro, Competition and Relationship Lending: Friends or Foes?, June 2010

3104 Dan Anderberg and Yu Zhu, The Effect of Education on Martial Status and Partner Characteristics: Evidence from the UK, June 2010

3105 Hendrik Jürges, Eberhard Kruk and Steffen Reinhold, The Effect of Compulsory Schooling on Health - Evidence from Biomarkers, June 2010

3106 Alessandro Gambini and Alberto Zazzaro, Long-Lasting Bank Relationships and Growth of Firms, June 2010 